\title{
A massive input of coarse-grained siliciclastics in the Pyrenean Basin during the PETM: the missing ingredient in a coeval abrupt change in hydrological regime
}

\author{
V. Pujalte ${ }^{1}$, J. I. Baceta ${ }^{1}$, and B. Schmitz ${ }^{2}$ \\ ${ }^{1}$ Dept. of Stratigraphy and Paleontology, Faculty of Science and Technology, University of the Basque Country (UPV/EHU), \\ Ap. 644, 48080 Bilbao, Spain \\ ${ }^{2}$ Division of Nuclear Physics, Department of Physics, University of Lund, P.O. Box 118, 22100 Lund, Sweden \\ Correspondence to: V. Pujalte (victoriano.pujalte@ehu.eus)
}

Received: 29 May 2015 - Published in Clim. Past Discuss.: 8 July 2015

Revised: 13 November 2015 - Accepted: 18 November 2015 - Published: 11 December 2015

\begin{abstract}
The Paleocene-Eocene thermal maximum (PETM) is represented in numerous shallow and deep marine sections of the south-central and western Pyrenees by a $2-4 \mathrm{~m}$ thick unit (locally up to $20 \mathrm{~m}$ ) of clays or marly clays intercalated within a carbonate-dominated succession. This unit records a massive input into the Pyrenean Gulf of fine-grained terrestrial siliciclastics, attributed to an abrupt hydrological change during the PETM. However, the nature of such a change remains controversial. Here we show that, in addition to fine-grained deposits, large volumes of coarsegrained siliciclastics were brought into the basin and were mostly accumulated in incised valleys and in a long-lived deep-sea channel. The occurrence of these coarse-grained deposits has been known for some time, but their correlation with the PETM is reported here for the first time. The bulk of the incised valley deposits in the PETM interval are cross-bedded sands and pebbly sands, almost exclusively made of quartz. The criteria for indicting a relation to the PETM include their stratigraphic position between upper Thanetian and lower Ilerdian marine carbonates, organic carbon isotope data, and a high percentage of kaolinite in the clay matrix. The axially flowing deep-sea channel existed throughout Paleocene times in the Pyrenean Basin, within which coarse-grained calciclastic and siliciclastic turbidites were accumulated. This Paleocene succession is capped by thickly bedded quartz sandstones and pebbly sandstones, probably deposited by hyperpycnal flows, which are here assigned to the PETM based on their stratigraphic position and organic carbon isotopic data. The large and simultaneous
\end{abstract}

increase in coarse- and fine-grained terrestrial siliciclastics delivered to the Pyrenean Gulf during the PETM is attributed to an increased intra-annual humidity gradient. During the PETM a longer and drier summer season facilitated the erosion of landscapes, whereas a dramatic enhancement of precipitation extremes during the wet season led to intensified flood events, with rivers carrying greater volumes of both bed and suspended loads. This scenario argues against the possibility that PETM kaolinites indicate a coeval warm and humid climate in northern Spain. Instead, the kaolinite reflects the erosion of thick Cretaceous lateritic profiles developed on the Hercynian basement.

\section{Introduction}

During the early Paleogene the Earth experienced several intervals of extreme warming, named hyperthermals. The most prominent and extensively studied is the Paleocene-Eocene thermal maximum (PETM; McInerney and Wing, 2011, and references therein). During this event, which started $\sim 56 \mathrm{Myr}$ ago and lasted $\sim 200 \mathrm{kyr}$, global temperatures rose between 5 and $8{ }^{\circ} \mathrm{C}$. The PETM was coeval with a large ( 3-5\%o) negative carbon isotope excursion (CIE) recorded in both marine and continental strata (e.g., Koch et al., 1992; Zachos et al., 2003; Bowen et al., 2001; Schmitz and Pujalte, 2003; Mangiocalda et al., 2004). This CIE is thought to record the release of $>2000 \mathrm{Gt}$ of ${ }^{13} \mathrm{C}$ depleted carbon into the ocean-atmosphere system (Dickens et al., 1997; Zachos et al., 2005). The source of the emitted carbon is still debated, 
dissociation of oceanic methane hydrates being the leading hypothesis (Dickens et al., 1995, 1997). The CIE associated with the PETM can be discriminated from other early Paleogene hyperthermal CIEs by its stratigraphic position: in the middle part of Chron C24r within planktonic foraminiferal biozone P5, near the boundary of calcareous nannofossil biozones NP9 and NP10 (Berggren and Aubry, 1998) and near the boundary of larger foraminifera shallow benthic zones (SBZ) 4 and 5 (e.g., Pujalte et al., 2003a, 2009; Scheibner et al., 2005). A kaolinite spike of controversial origin is also present in many, but not all, PETM sections (e.g., Gibson et al., 2000; Thiry and Dupuis, 1998, 2000; Quesnel et al., 2011; Dypvik et al., 2011; John et al., 2012).

The PETM is considered a possible ancient analogue of the current warming of the Earth climate, a process expected to alter the global hydrological cycle because a warmer atmosphere can hold more moisture. The possible effects of such a change have been reconstructed through modeling (e.g., Murphy et al., 2004; Held and Soden, 2006; Beniston et al., 2007; Allan and Soden, 2008; Berg and Hall, 2015). According to these studies the character of the expected changes in precipitation will vary from region to region. A proper understanding of the PETM hydrological changes, therefore, requires a global data base.

Hydrological changes induced by the PETM have been reported in various studies, which suggest drier conditions for some midlatitude areas (e.g., Wing et al., 2005; Handley et al., 2012) and wetter conditions at high latitudes (e.g., Pagani et al., 2006). In the terrestrial Bighorn Basin these changes are recorded by alterations of alluvial architecture (e.g., Foreman et al., 2012; Foreman, 2014) and/or in the stacking pattern and type of paleosols (Kraus et al., 2013, 2015). Increased influxes of terrestrial clays into widely separated continental margins during the PETM have also been attributed to a coeval change in hydrology, for instance on the west and east coast of the USA (e.g., Gibson et al., 2000; John et al., 2008) and in New Zealand (e.g., Slotnick et al., 2012).

The PETM is recorded in the southern and western Pyrenees (northern Spain) in outcropped sections of a continuous range of facies (Fig. 1), a circumstance that offers the unique opportunity to study the associated hydrological changes on a complete transect of the same basin, from terrestrial to deep marine settings. In marine sections the PETM is represented by a fine-grained siliciclastic unit (FSU) intercalated within a carbonate-dominated succession. The FSU is usually 2 $4 \mathrm{~m}$ thick, exceptionally up to $20.5 \mathrm{~m}$, and consists predominantly of fine-grained calcareous mudstones. Carbonate content of the FSU in shallow marine sections ranges from 20 to $45 \%$, the carbonate fraction being largely represented by tests of larger foraminifera (Pujalte et al., 2003a). The FSU carbonate fraction in deep marine sections is lower $(0-10 \%)$, being partly represented by an impoverished assemblage of foraminifera and calcareous nannofossils (Schmitz et al., 1997; Orue-Etxebarria et al., 2004; Alegret et al., 2009).
These data demonstrate that a massive influx of terrestrial fine-grained siliciclastics was delivered to the Pyrenean Gulf during the PETM, diluting but not entirely suppressing the autochthonous carbonate accumulation. It is generally agreed that this fine-grained siliciclastic influx was due to an abrupt hydrological change in the Pyrenean Gulf region during the PETM. The nature of such change, however, is controversial, some papers arguing in favor of intensified precipitation (e.g., Pujalte et al., 1998a; Adatte et al., 2000), others in favor of increased aridity (e.g., Bolle et al., 1998; Schmitz et al., 2001). Bolle et al. (1998) argued that kaolinite from the Ermua section was brought from lower latitudes by oceanic currents while arid conditions prevailed in the adjacent coastal area. The proposal by Schmitz et al. (2001) was partly based on a tentative correlation of the FSU with prominent evaporite deposits in the terrestrial Tremp area (Fig. 1). However, subsequent studies by Schmitz and Pujalte $(2003,2007)$ established a robust correlation of the FSU with units of the Tremp area indicative of an enhanced seasonal humidity gradient during the PETM (i.e., the Claret Conglomerate and the yellowish soils). More recently, Clare et al. (2015) suggested that a hot and arid climate during the PETM may have reduced the turbidity current activity in the Basque Basin immediately before and during the thermal event.

This paper is based on the study of new Paleocene-Eocene (P-E) boundary sections situated in the western Pyrenees (Fig. 1). The main purposes of the paper are to try to locate the PETM in these sections and to test whether there is additional evidence of changes in the hydrological regime during the event. The most important finding is that, in addition to a massive influx of fine-grained siliciclastics, important volumes of coarse-grained quartz sands and pebbly sands were supplied to the Pyrenean Gulf during the PETM. The coarse-grained siliciclastics were accumulated in two different depositional environments, namely within a broad deep-sea channel and within incised valleys. It will also be shown that kaolinite from the FSU was probably supplied from Cretaceous lateritic profiles developed on the adjacent Hercynian basement of northern Spain and that turbidite activity increased, rather than decreased, during the PETM.

\section{Setting and background information}

\subsection{Paleogeography}

Throughout early Paleogene times the Pyrenean domain was an E-W elongated marine gulf, opening into the Bay of Biscay, situated in the subtropical net evaporation zone $\left(35^{\circ} \mathrm{N}\right)$. The gulf had a central deep-water trough (Basque Basin) flanked by a broad shallow marine carbonate platform, in turn surrounded by subaerial alluvial plains (Fig. 1; Plaziat, 1981; Baceta, 1996; Baceta et al., 2011). The alluvial plains in the Tremp area were fed with calciclastic deposits derived from Cretaceous carbonate rocks uplifted in the eastern Pyrenees. In addition, the Massif Central in France and the Ebro 


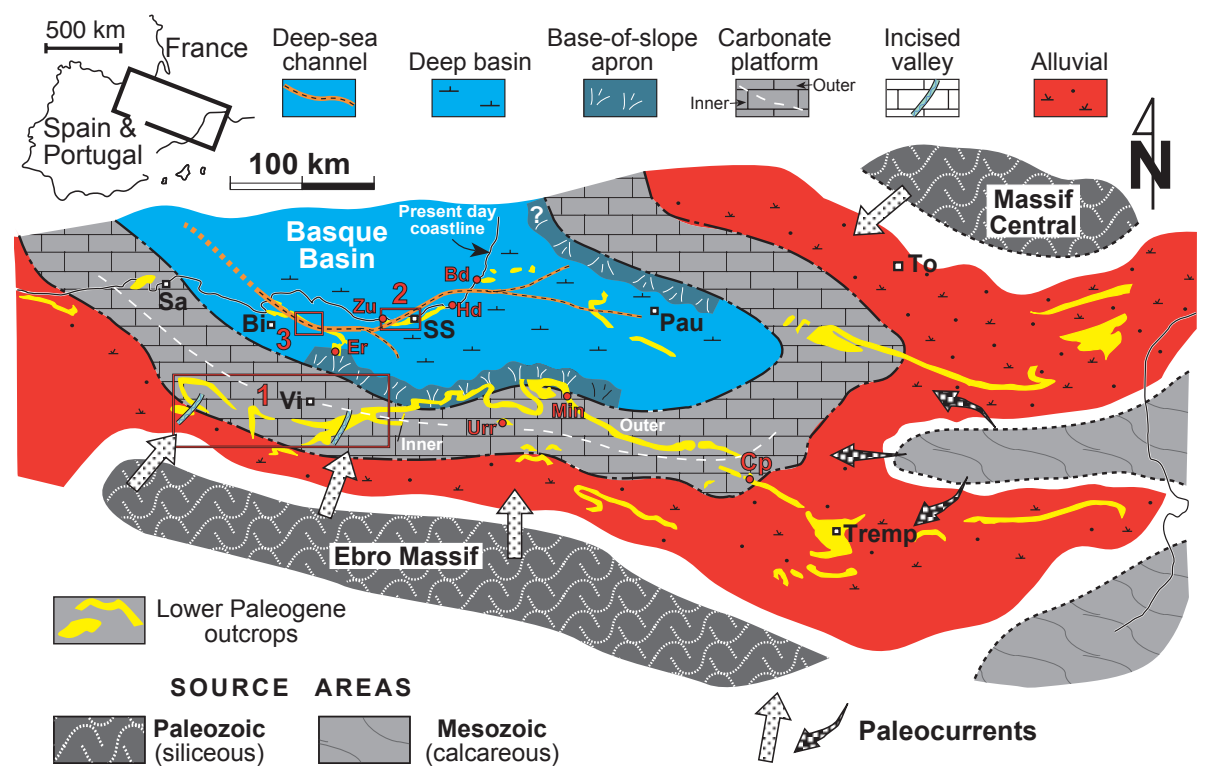

Figure 1. Early Paleogene paleogeography of the Pyrenean area (modified from Baceta et al., 2004). The separation of inner and outer platform domains (white broken line) is approximate. Boxes mark the location of study areas (1: incised valleys; 2 and 3: deep-sea channel segments). Note different source areas, supplying calciclastic and siliciclastic deposits. Reference sections (in red): Bd - Bidart; Cp - Campo; Er - Ermua; Hd - Hendaia; Mi - Mintxate; Ur - Urrobi; Zu - Zumaia. Main cities: Bi - Bilbao; Sa - Santander; SS - San Sebastian; Vi Vitoria; To - Toulouse; Pau; Tremp.

Massif in Spain, both mostly made up of Paleozoic rocks, supplied siliciclastic sediments (Fig. 1). The carbonate platform is represented by a stack of shallow-marine carbonates up to $300 \mathrm{~m}$ thick. It can be broadly subdivided into inner and outer platform domains (Fig. 1) based on fossil content and dolomite / limestone proportions. Significant amounts of sand and sandstone also occur, some of which accumulated within valleys incised in the inner platform domain (Baceta et al., 1994; Pujalte et al., 2014a). Basinward from the carbonate platform edge a carbonate base-of-slope apron developed, which evolved down current to the deep marine Basque Basin. The deep-sea channel flowed along the axial part of this basin (Fig. 1).

This paper focuses on the incised fluvial valleys and on the deep-sea channel, discussing the architecture and facies of their deposits across the P-E interval. To place the new data in context, however, prior information about well-studied marine P-E sections of the Pyrenean Gulf is summarized below.

\subsection{Main P-E marine reference sections of the Pyrenees}

The most representative and well-studied P-E sections of the inner carbonate platform, base-of-slope apron and deep basin settings of the Pyrenees are, respectively, Campo, Ermua and Zumaia (Figs. 1 and 2).

The P-E interval is represented at Campo by deposits of three discontinuity-bounded depositional sequences (DS TH-
2, DS Il-1 and DS-Il2; Baceta et al., 2011). These sequences are mostly composed of shallow marine calcarenites and calcareous sandstones rich in larger foraminifera, with planktonic microfossils occurring at some intervals (Fig. 2). The short normal Chron C25n was identified near the base of the DS TH-2 (Pujalte et al., 2003b). The DS Il-1 begins with an interval of terrestrial origin that rests on a surface of subaerial exposure that developed at the top of DS TH-2. The PETM has been pinpointed within that terrestrial interval (Fig. 2; Schmitz and Pujalte, 2003; Baceta et al., 2011).

The Ermua section contains the thickest FSU reported to date in marine successions of the Pyrenees (20.5 m; Pujalte et al., 1994), its attribution to the PETM being based on highresolution isotopic profiles of bulk rock samples (Bolle et al., 1998; Schmitz et al., 2001) and further constrained by biostratigraphy (Orue-Etxebarria et al., 1996)

The Zumaia section is the most complete and representative section of the deep-water Basque Basin across the P-E interval (e.g., Baceta et al., 2000). The $4 \mathrm{~m}$ thick FSU occurs within an alternation of marls and marly limestones, with intercalated thin-bedded turbidites, rich in benthic and planktonic foraminifera and calcareous nannofossils (e.g., Schmitz et al., 1997; Orue-Etxebarria et al., 2004; Alegret et al., 2009). The Zumaia FSU is ascribed to the PETM based on biostratigraphically constrained isotopic profiles of both bulk rock carbonate samples (Schmitz et al., 1997) and dispersed organic carbon (Storme et al., 2012). The polarity Chron C25n was delineated from 35 to $25 \mathrm{~m}$ below the base of the FSU (Fig. 2; Dinarès-Turell et al., 2002). 


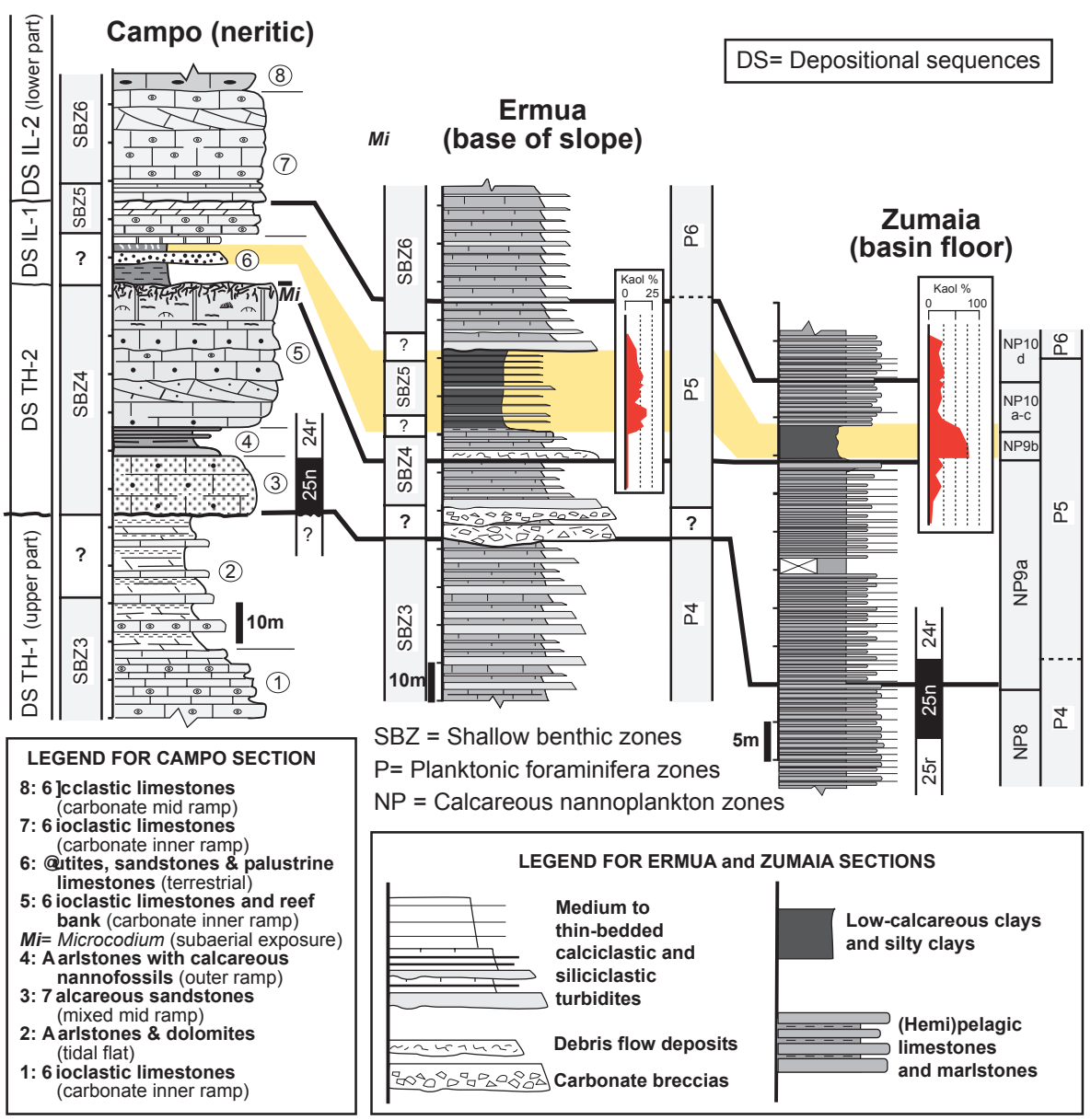

Figure 2. Simplified logs of the Paleocene-Eocene interval of well-studied marine sections of the Pyrenees in which the PETM has been identified (highlighted). Biostratigraphic zonations, the position of Chron C25n and graphs of kaolinite abundance are also shown.

\section{Data set and methods}

This paper is mainly based on the study of three zones of the western Pyrenees, indicated by boxes 1, 2 and 3 in Fig. 1. After a detailed geological mapping of these zones, the P-E interval of selected sections was logged and sampled. Thirty-two samples were studied for organic carbon isotopes of dispersed organic matter and two samples for inorganic carbon isotopes of soil carbonate nodules. Analyses of the organic carbon $\left(\delta^{13} \mathrm{C}_{\text {org }}\right)$ were carried out at the Servizos de Apoio á Investigación (SAI) of the University of A Coruña, Spain. Samples were weighed in silver capsules, decarbonated using $25 \% \mathrm{HCl}$ and measured by continuous flow isotope ratio mass spectrometry using a MAT253 mass spectrometer (ThermoFinnigan) coupled to an elemental analyzer EA1108 (Carlo Erba Instruments) through a Conflo III interface (ThermoFinnigan). Carbon isotope abundance is expressed as $\delta^{13} \mathrm{C}_{\text {org }}(\% o)$ relative to VPDB (Vienna Pee Dee Belemnite). International reference standards (NBS-22, IAEA-CH-6 and USGS 24) were used for $\delta^{13} \mathrm{C}$ calibration. Replicate analyses were carried out on six of the decar- bonated samples, which revealed mean standard deviations $\leq 0.1 \%$ o (Table 1). Extraction of $\mathrm{CO}_{2}$ from the two samples of soil carbonate nodules was performed by reaction with orthophosphoric acid $\left(90^{\circ} \mathrm{C}\right)$ and analyzed in an ISOCARB device attached to aVG-Isotech SIRA-IITM mass spectrometer (both VG Isogas Co., Middlewich, United Kingdom) at the Universidad de Salamanca, Spain. The accuracy was monitored by repeated analysis of both internal and international (NBS-19) carbonate standards under identical analytical conditions. Isotope results are given as $\delta^{13} \mathrm{C}_{\text {inorg }}(\%)$ relative to VPDB standard.

Fine-grained samples were analyzed for their clay minerals by X-ray diffraction (XRD) using a PANalytical Xpert PRO diffractometer at SGIker X-ray Facility of the University of the Basque Country, Spain. Samples were mechanically ground and decarbonated using diluted $\mathrm{HCl}$. The resulting suspension was centrifuged until total removal of chlorides. The $<2 \mu \mathrm{m}$ fraction was separated and concentrated by centrifugation. Oriented aggregates of this fraction were analyzed by XRD following three steps: first, air-drying without any additional treatment; second, ethylene glycol solva- 


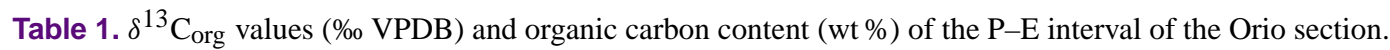

\begin{tabular}{llll|lllr}
\hline Sample & Lithology & $\delta^{13} \mathrm{C}_{\text {org }}$ & wt $\%)$ & Sample & Lithology & $\delta^{13} \mathrm{C}_{\text {org }}$ & wt \%) \\
\hline OR-1 & Clay & -24.30 & 0.40 & OR-12 & Clay $^{c}$ & -28.17 & 0.47 \\
OR-1r & Clay & -24.40 & 0.40 & OR-13 & Clay $^{c}$ & -28.26 & 1.09 \\
OR-2 & Clay & -24.20 & 0.33 & OR-14 & Clay & -28.00 & 5.94 \\
OR-3 & Clay & -24.30 & 0.05 & OR-14r & Clay & -27.94 & 6.27 \\
OR-4 & Clay & -23.80 & 0.10 & OR-15 & Clay & -28.40 & 1.05 \\
OR-5 & Clay & -24.30 & 0.29 & OR-16 & Clayc & -25.70 & 0.30 \\
OR-6 & Clay & -24.40 & 0.41 & OR-17 & Clayc & -27.60 & 0.39 \\
OR-7 & Clay & -24.80 & 0.50 & OR-18 & Coal remains & -27.90 & 29.90 \\
OR-7r & Clay & -24.80 & 0.60 & OR-19 & Clayc & -27.30 & 0.10 \\
OR-8 & Clayc & -25.70 & 0.20 & OR-20 & Clayc & -28.00 & 0.50 \\
OR-8r & Clayc & -25.50 & 0.20 & OR-21 & Clay & -27.70 & 0.50 \\
OR-9 & Clayc & -27.70 & 0.30 & OR-22 & Marls & -24.80 & 0.62 \\
OR-9r & Clayc & -27.60 & 0.30 & OR-23 & Marly limestone & -25.10 & 0.70 \\
OR-10 & Clayc & -27.70 & 0.30 & OR-23r & Marly limestone & -25.40 & 0.80 \\
OR-11 & Clayc & -27.90 & 0.60 & & & & \\
\hline
\end{tabular}

Location of samples in Fig. $11 .^{c}$ denotes clay clast. Samples with $\mathrm{r}$ indicate replicate analysis.

tion for $48 \mathrm{~h}$ at room temperature in order to identify smectite; and, third, dimethyl sulfoxide solvation at $75^{\circ} \mathrm{C}$ for $72 \mathrm{~h}$ in order to identify kaolinite and chlorite. Semiquantitative abundances were assessed using the intensity (area) of the major XRD reflections following the protocol developed by Schultz (1964).

The petrology of 22 sandstone samples was examined in thin sections under a Nikon polarized light microscope. This paper also makes use of stratigraphic and micropaleontological data from previous studies, mainly van Vliet (1982), Pujalte et al. (1994), Baceta (1996), Orue-Etxebarria et al. (1996, 2004) and Baceta et al. (2011).

\section{Results}

\subsection{The P-E interval in the inner carbonate platform}

The P-E interval is represented in the inner carbonate platform of the southwestern Pyrenees by two different kinds of successions, typified by the Korres and Laminoria sections (Figs. 3 and 4). The Korres section is mostly comprised of shallow marine carbonates, and it is illustrative of zones flanking the incised valleys. The Laminoria section, on the other hand, includes massive volumes of siliciclastic sediments of terrestrial origin that infill elongated, large-scale erosional depressions interpreted as incised valleys, the orientation of which was reconstructed with paleocurrents (Baceta et al., 1994; Fig. 3b).

Two incised valleys have been recognized, situated to the southeast and to the west of the city of Vitoria (Figs. 1, 3a). Their best outcrops occur in the Laminoria and Villalain quarries, after which the valleys have been named. A width of about $6 \mathrm{~km}$ is estimated for the Laminoria valley (Fig. 3b). Width of the Villalain valley was probably similar, although outcrop constrains preclude its accurate reconstruction. Elsewhere in the southern Pyrenees, lower Paleogene inner platform deposits are either eroded or buried under younger deposits (Fig. 1).

\subsubsection{Korres section}

The Korres section $\left(42^{\circ} 41^{\prime} 55^{\prime \prime} \mathrm{N}, 2^{\circ} 26^{\prime} 11^{\prime \prime} \mathrm{W}\right)$ is situated about $1 \mathrm{~km}$ east of the extrapolated eastern margin of the Laminoria incised valley (Fig. 3b). The P-E interval of the section comprised the same discontinuity-bounded depositional sequences as in the Campo section (DS TH-2 and DS IL-1; Baceta et al., 2011). The correlation with Campo is based on the fact that the Korres sequences contain marine microfossils of the shallow benthic zones SBZ-4 (late Thanetian) and SBZ-5 (early Ilerdian, i.e., lowest Ypresian) of Serra-Kiel et al. (1998) (Fig. 4; fossil determination by Serra-Kiel, in Pujalte et al., 1994).

Depositional sequence TH-2 rests abruptly on lower Thanetian recrystallized limestones and dolomitic marls and has two parts (Fig. 4). The lower part $(\sim 10 \mathrm{~m})$ is made up of an alternation of cross-bedded sandy limestones and sandy marls, the upper one $(\sim 20 \mathrm{~m})$ of thickly bedded grainstones and sandy grainstones with algal remains and larger foraminifera. As in Campo, the DS TH-2 is capped at Korres by a subaerial exposure surface of uneven morphology, the unevenness caused by a dense array of subvertical downtapering pipes up to $20 \mathrm{~cm}$ in diameter and no less than $1 \mathrm{~m}$ deep (Figs. 4, 5a, b). The pipe fills have a distinctive rugged appearance in weathered surfaces, caused by numerous hardened coated grains enclosed within a matrix of sandy calcarenites (Fig. 5c, d). Diameters of the coated grains vary between 2 and $35 \mathrm{~mm}$, the smaller ones being spherical, the large ones ovoidal in shape (Fig. 5d). They have large nu- 


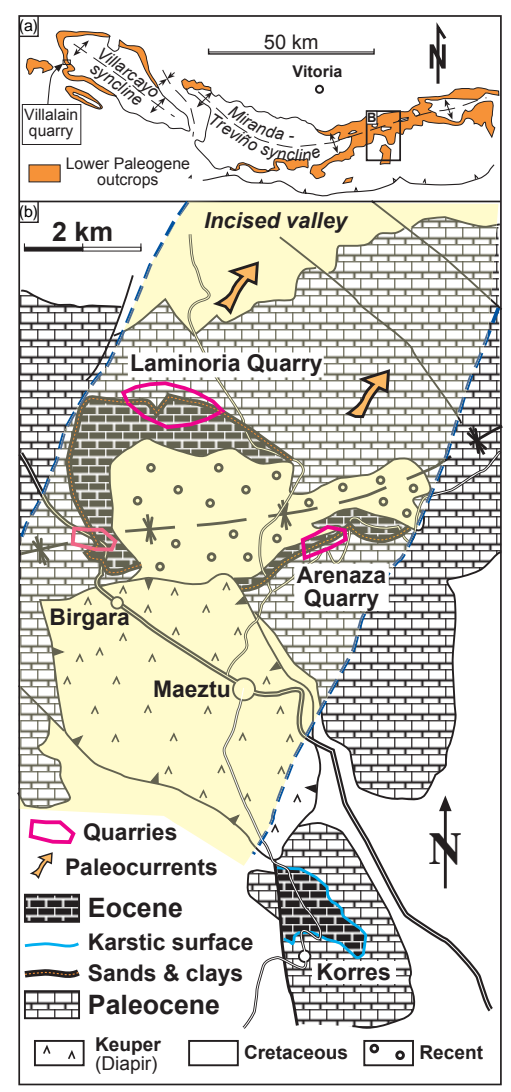

Figure 3. Panel (a): lower Paleogene outcrop map of the southwestern Pyrenees, with location of the Laminoria-Korres area and the Villalain quarry. Panel (b): enlarged outcrop map of the LaminoriaKorres area, with an interpretative plan view of the Laminoria incised valley.

clei and thin cortices. The nuclei are formed of quartz grains and lithoclasts set in a micritic matrix, the cortices of vaguely laminated micrite with irregularly developed circumgranular cracks (Fig. 5e).

Vertical to subvertical pipes with coated grains similar to those of the Korres section were described in recent soils of Tarragona, Spain, by Calvet and Julià (1983, p. 457, their Fig. 1b) and in the British West Indies by Jones (2011, p. 97, his Fig. 2a), who respectively named them pisoids and oncoids. In both cases the pipes with coated grains were developed around roots of trees and bushes penetrating the rocky Miocene substratum. By analogy, it seems logical to conclude that the surface capping the DS TH-2 at Korres was subaerially exposed and colonized by plants.

The DS IL-1 has two parts at Korres, the lower one of terrestrial origin, the upper one of shallow marine character. The lower part ( $7 \mathrm{~m}$ thick, hereafter named unit D; Fig. 4) is made up of grey calcareous clays containing scattered small-sized $(<3 \mathrm{~mm})$ carbonate nodules indicative of poorly developed soils. The overlying marine part (>15 m thick, top not preserved) is mostly composed of sandy calcarenites with abun- dant shallow marine microfossils, notably flosculinized alveolinids (Fig. 4). These calcarenites pertain to the so-called Alveolina limestone, a laterally extensive marine unit of the Pyrenees that records a basin-wide, early Eocene transgression (e.g., Plaziat, 1981; Baceta et al., 2011; Pujalte et al., 2014a).

\subsubsection{Laminoria and Villalain sections}

Laminoria $\left(42^{\circ} 46^{\prime} 45^{\prime \prime} \mathrm{N}, 2^{\circ} 28^{\prime} 00^{\prime \prime} \mathrm{W}\right)$ and Villalain $\left(42^{\circ} 54^{\prime} 43^{\prime \prime} \mathrm{N}, 3^{\circ} 35^{\prime} 19^{\prime \prime} \mathrm{W}\right)$ are two active quarry sections exposing incised valley successions. Similar deposits are partially outcropped in two other inactive quarries, Arenaza and Birgara (Fig. 3). In these four quarries the DS TH-2 is truncated by an erosional unconformity, the truncation involving the removal of at least $21 \mathrm{~m}$ of the sequence (Figs. 4 and 6a). The unconformity is overlain by the terrestrial part of DS IL-1, in which three successive lithologic units are recognized (units A, B and C in Fig. 4).

Unit A is poorly outcropped in a few scattered outcrops (Fig. 6a). Exploratory shallow boreholes demonstrate that it is up to $7 \mathrm{~m}$ thick (J. R. Subijana, personal communication, March 2015). It is composed of red unfossiliferous clays with subordinate interbedded sand lenses. Neither carbonate nodules nor carbonate-coated rhizocretions have been observed in the clays, only occasional root traces about $1 \mathrm{~mm}$ in diameter. The sandstone lenses consist of very fine to fine quartz grains cemented by carbonate. The lenses range in thickness from 0.5 to $4 \mathrm{~cm}$, exhibiting cross-laminations, sharp bases and undulating tops.

Unit $\mathrm{B}$ is up to $10.5 \mathrm{~m}$ thick and mainly composed of fineto medium-grained $(0.1-0.7 \mathrm{~mm})$ quartz sands containing up to $20 \%$ of clay matrix. Other components are pebbles, ranging $1-10 \mathrm{~cm}$ in diameter, which occur randomly dispersed in the sands (Fig. 6b). Most clasts are subrounded fragments of white or pink vein quartz, but clasts of metamorphic quartzite and of sedimentary quartzarenite also occur. Some of the bigger clasts exhibit distinctive polished flattened facets of ventifacts (Fig. 6c). These ventifacts most likely originated from Permian rocks, where they are comparatively abundant. They are commonly found resedimented into younger formations (Segura and Elorza, 2013). The quartz sands exhibit light brownish colors in the active front of the quarries but have acquired a superficial reddish color in the inactive Arenaza quarry (Supplement Fig. S1a; location in Fig. 3). Furthermore, the topmost $10-15 \mathrm{~cm}$ of the sands in the Arenaza quarry are intensely impregnated by hematite (Supplement Figs. S1b, c).

Neither body fossils nor trace fossils have been observed in unit B, although hematite-coated root casts occur at some levels (Fig. 6e). Meter-thick cross-bedded sets bounded by erosional surfaces are clearly visible at Laminoria and Villalain (Fig. 6d, f). The shapes of the bounding surfaces are concave-up in the Laminoria quarry front, which is oriented at almost right angles to the paleocurrents, and they are near- 


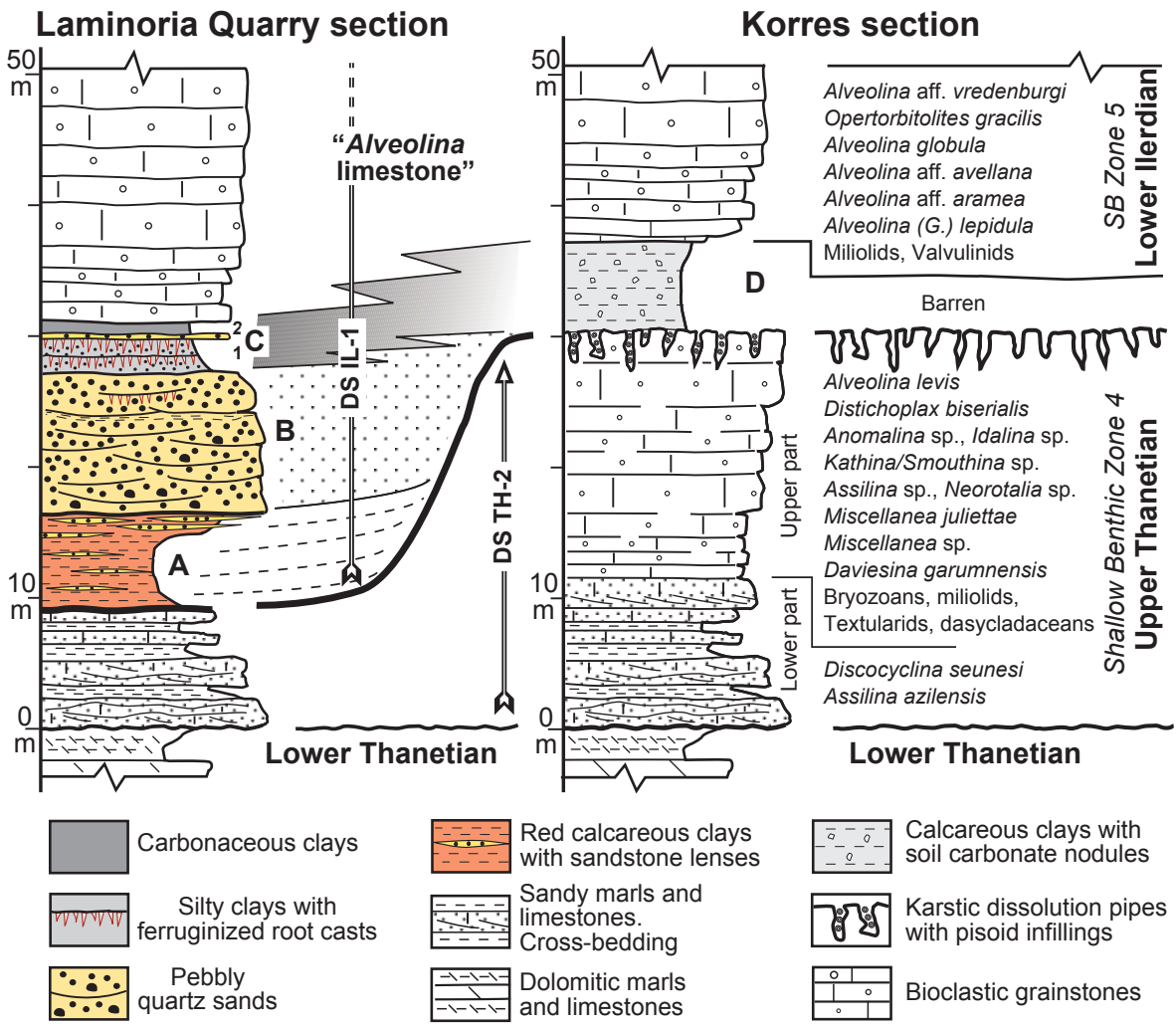

Figure 4. Columnar sections of the Laminoria quarry and Korres sections across the Paleocene-Eocene interval. DS: depositional sequences. A-D: terrestrial lithologic units described in the text.

flat in the Villalain quarry front, oriented nearly parallel to the paleocurrents (Fig. 6d, f). Furthermore, unidirectional cross-stratification of decimeter to meter scale foresets can be clearly perceived at Villalain (Fig. 6f). These geometries are indicative of large-scale unidirectional trough cross-bedding, a type of bedding amply described in fluvial deposits (e.g., Allen, 1983; Bridge, 2003). The absence of marine body fossils or trace fossils, and the occasional occurrence of roots, supports the fluvial interpretation.

Unit $C$ is up to $4 \mathrm{~m}$ thick and caps the incised valley succession in both the Laminoria and Villalain quarries (Fig. 6d, f). At Laminoria, unit $\mathrm{C}$ has two parts (Figs. 4 and $6 \mathrm{~d}$, e). Part C1 (3 m) consists of silts with intercalated sand beds 5$10 \mathrm{~cm}$ thick, with at least two horizons crowded with root casts coated with iron oxides (Figs. 4, 6e). Part C2 (1 m) is solely composed of dark-grey carbonaceous clays. At Villalain only part $\mathrm{C} 2$ is represented (Fig. 6f). Unit $\mathrm{C}$ is sharply overlain in both quarries by the Alveolina limestone unit, with the abrupt lower boundary most likely representing a ravinement surface recording the Ilerdian transgression.

\subsection{Paleocene deposits in the Basque Basin}

The Paleocene Epoch is represented in the Basque Basin by two contrasting and mutually exclusive groups of deposits, autochthonous hemipelagic and allochthonous turbidites and breccias. Hemipelagic deposits are represented by cyclic vertical alternations of marls and limestones, with minor intercalations of thin-bedded turbidites. These deposits have been intensively studied, particularly in the Zumaia section but also in other sections such as Trabakua pass, Sopelana, Hendaia or Bidart (Fig. 1) (e.g., Dinarès-Turell et al., 2014; Storme et al., 2014; Le Callonnec et al., 2014; Clare et al., 2015; Hilgen et al., 2015, to name but a few recent publications). The Zumaia section also includes the Global Stratotype Sections and Points for the Selandian and Thanetian stages (Schmitz et al., 2011).

There are two groups of allochthonous deposits. One group corresponds to the calciclastic breccias and thickly bedded calciturbidites of the base-of-slope carbonate apron (Fig. 1). The Ermua section is representative of this group (Pujalte et al., 1994; Baceta, 1996; Schmitz et al., 2001). The second group includes, in addition to coarse-grained calciclastic deposits, important volumes of siliciclastic turbidites (Figs. 7-10). 

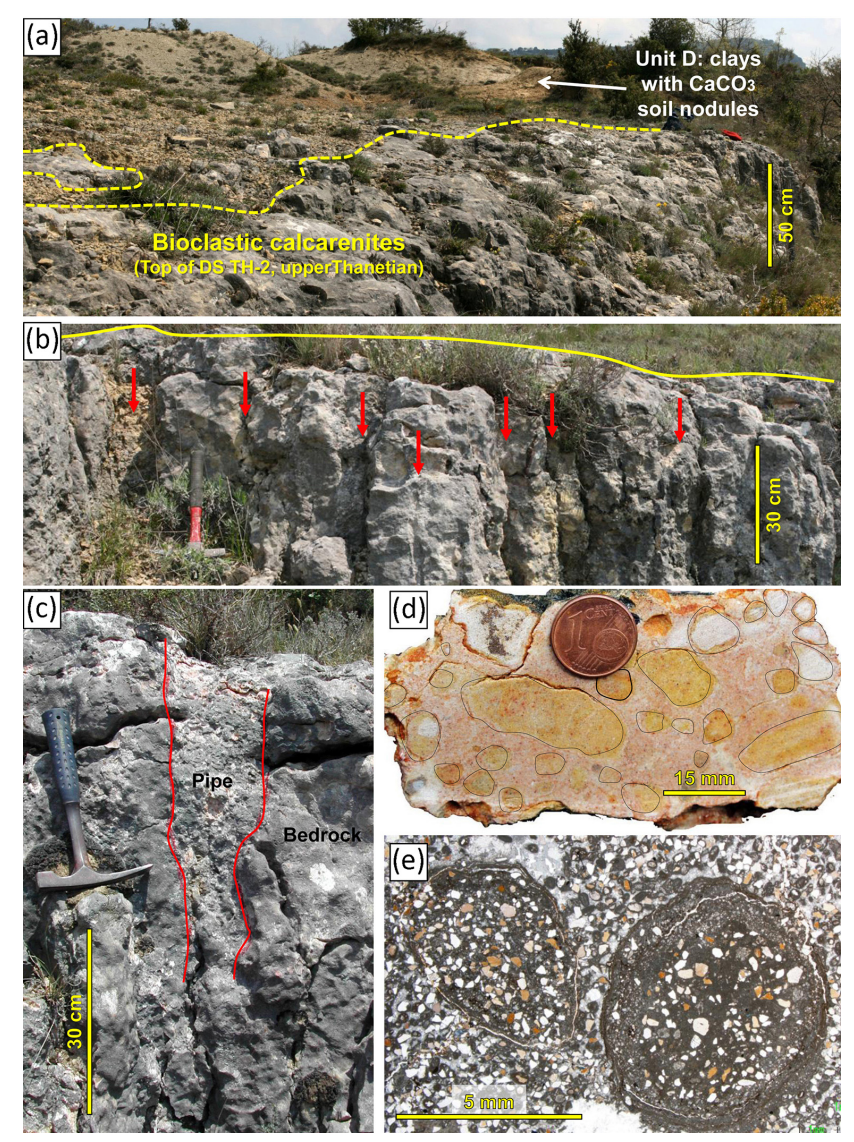

Figure 5. Field images of the Korres section. Panel (a): general view of the irregular surface capping the upper Thanetian marine carbonates of DS TH-2 and of the overlying terrestrial unit D. Panels $(\mathbf{b}, \mathbf{c})$ : overview and close-up of the prominent vertical dissolution pipes coming down from the top surface of DS TH-2. Panels (d, e): polished hand sample and microphotograph of the pisoidbearing infilling of the dissolution pipes.

Allochthonous, or resedimented, deposits of the second group occur in the axial part of the Basque Basin and were, until recently, largely overlooked and misinterpreted. Thus, although their existence near Orio (location in Figs. 1, 7) was reported more than 60 years ago (Gómez de Llarena, 1954), only two papers about them were produced in the following 28 years (Hanisch and Pflug, 1974; van Vliet, 1982). In the first paper the resedimented deposits were considered a Cretaceous diapiric mass that outflowed from the nearby Zarautz diapir (Fig. 7b). The second paper provided a correct dating of the succession with calcareous nannoplankton (Fig. 7a, a'), but the only interpretation offered was that "this area [near Orio] remains stratigraphically anomalous until the earliest Eocene, as it also contains a localized very coarse-grained submarine fan body in the basal Tribrachiatus contortus zone (NP 10)" (van Vliet, 1982, pp. 32). Later studies by Pujalte et al. (1994) and Baceta (1996) made it evident
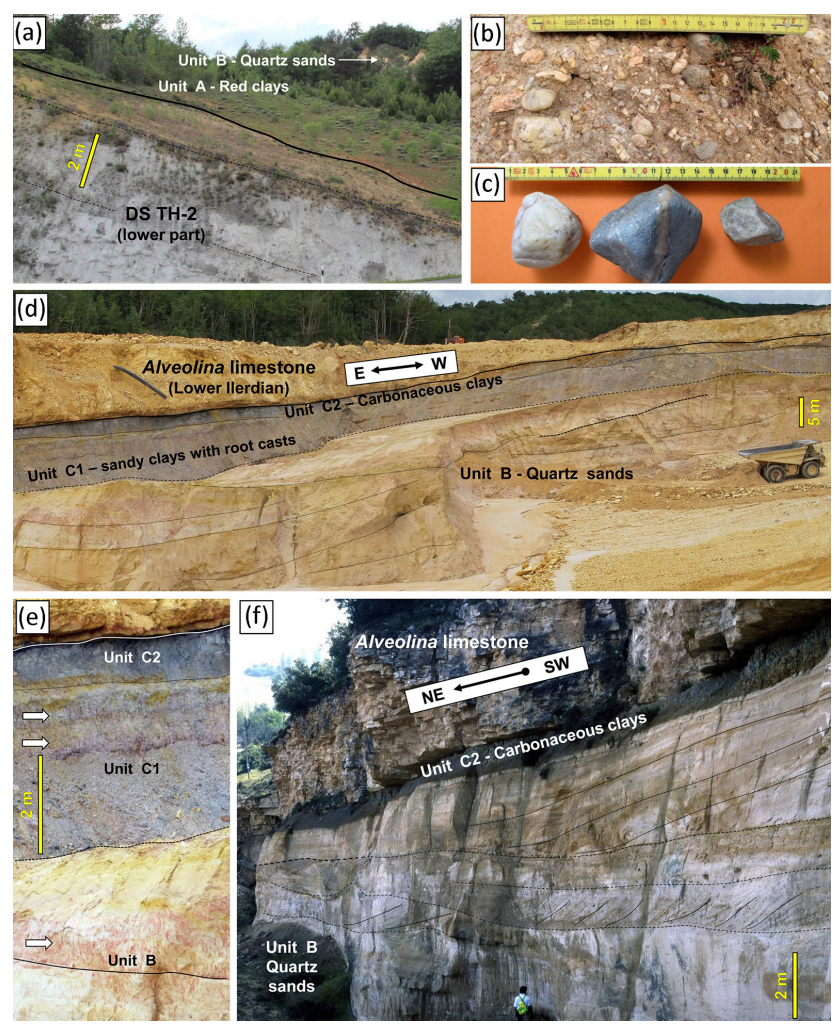

Figure 6. Incised valley deposits. Panel (a): abandoned quarry to the north of Birgara: general view of terrestrial unit A abruptly overlying upper Thanetian sandy marls and limestones of DS TH-2. Panel (b): close-up of a pebble-rich part of unit B. Panel (c): examples of subrounded pebbles of unit B with flattened facets suggestive of ventifacts. Panel (d): general view of terrestrial units B and $\mathrm{C}$, and of the overlying Alveolina limestone, in the active front of the Laminoria quarry. Note concave-up internal erosional surfaces in unit B (quartz sands). The dumper is about $6.5 \mathrm{~m}$ high. Panel (e): close-up of a part of the Laminoria quarry front, the white arrows indicating horizons with hematite-coated root casts. Panel (f): terrestrial units B and C in the Villalain Quarry; note large-scale unidirectional cross-bedding in unit $\mathrm{B}$.

that the second group of resedimented deposits were accumulated within an axially flowing deep-sea channel (Fig. 1).

\subsubsection{The deep-sea channel deposits}

Deep-sea channels are erosional submarine features deeply incised into unconsolidated sediment of ocean-margin troughs or abyssal plains (Carter, 1988). The main evidence that the Paleocene resedimented deposits were accumulated within a deep-sea channel is that they occur within an elongate erosional depression that extends from near Pau to near Bilbao (Fig. 1; Baceta, 1996; Pujalte et al., 1998b).

Flute casts from thick-bedded turbidites of the deep-sea channel systematically indicate westward-directed paleocurrents. In the case of Orio, paleocurrents demonstrate transport towards the Zarautz diapir, not away from it (Fig. 7b). 


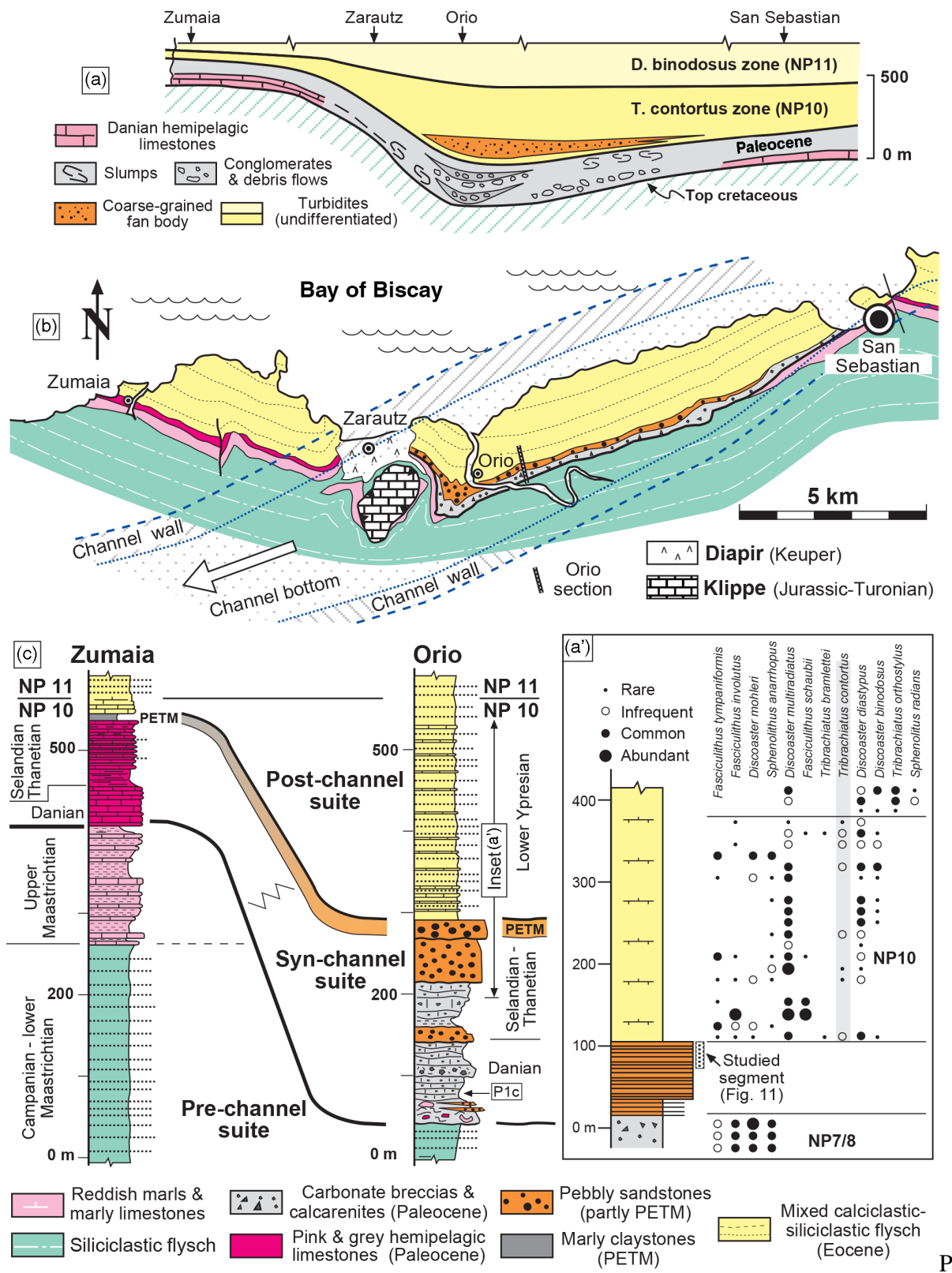

Figure 7. (a, a'): stratigraphic cross section of the Zumaia-San Sebastian area and calcareous nannoplankton zonation of a part of the Orio section (after van Vliet 1982, redrawn from his Fig. 60 and his enclosure 3). Note that the Cretaceous part in the cross section is undifferentiated. Panel (b): outcrop map with superimposed paleogeography of a segment of the Paleocene deep-sea channel from the same area (location: box 2 in Fig. 1). Panel (c): correlation of the Orio and Zumaia sections using the NP10-NP11 boundary as datum.

Furthermore, high-resolution mapping demonstrated that the Zarautz diapir had little influence on the accumulation of the resedimented deposits (Baceta et al., 1991). The trend of the deep-sea channel was inferred from paleocurrents, its cross section through correlation of well-dated sections using the lower-upper Maastrichtian, the Cretaceous-Paleogene and the NP10-NP11 boundaries as tie points (Figs. 7, 9). These data demonstrate that the Paleocene deep-sea channel was at least $200 \mathrm{~km}$ long, about $5 \mathrm{~km}$ wide and up to $350 \mathrm{~m}$ deep (i.e., the maximum thickness of the missing section at Orio and Gonzugaraia; Figs. 7, 8).

A chaotic breccia at the base of the resedimented succession near Orio includes contorted blocks of upper Maastrichtian reddish marls and large clasts of hemipelagic limestones of the Paleocene planktonic foraminifera P1a Zone of Berggren et al. (1995). The breccia is overlain by thickly bedded calciturbidites with thin marly interbeds containing wellpreserved planktonic foraminifera of the P1c Zone (Fig.7c; 


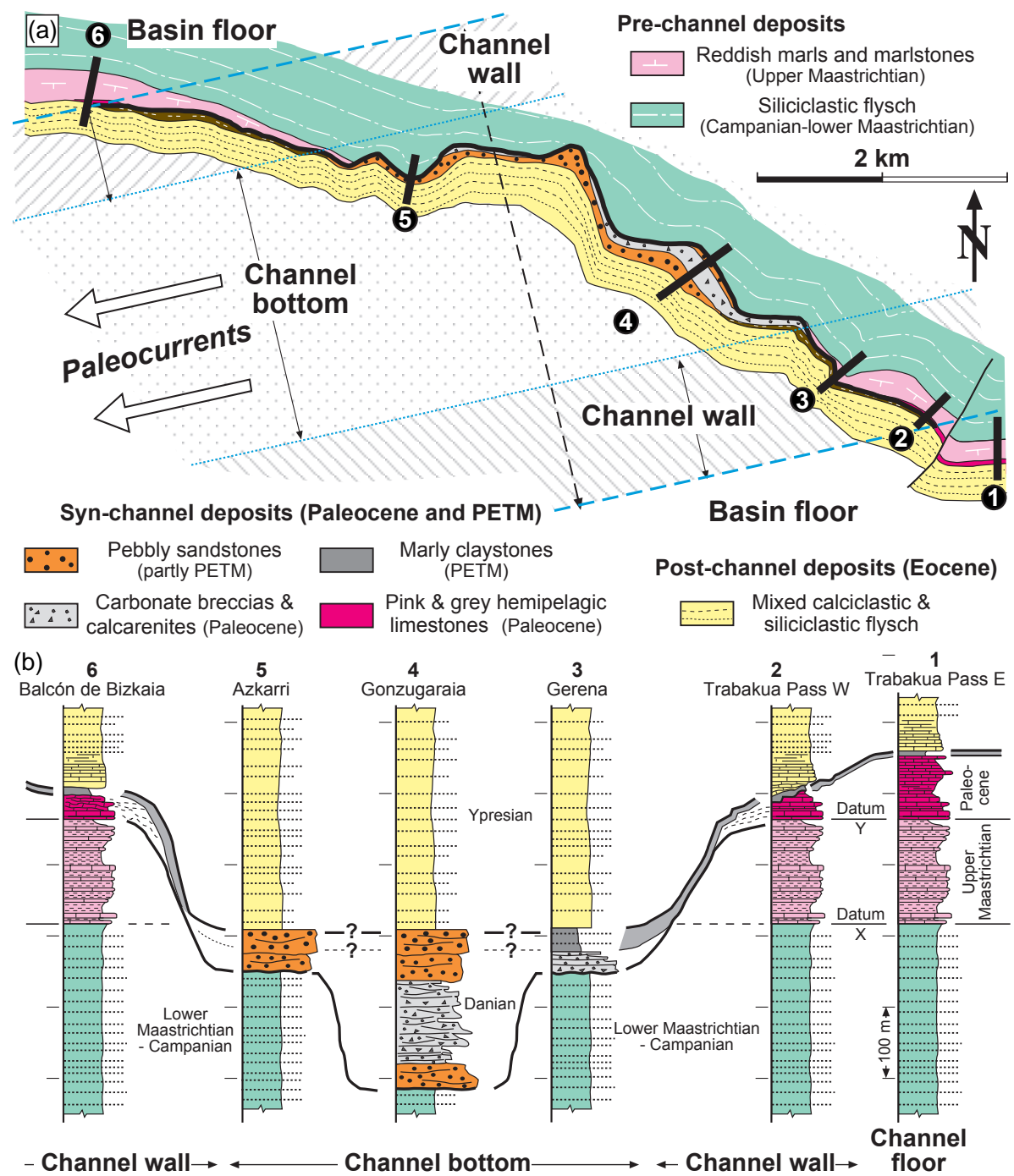

Figure 8. Panel (a): outcrop map with superimposed paleogeography of a segment of the Paleocene deep-sea channel from the GonzugaraiaTrabakua pass area (location: box 3 in Fig. 1). Panel (b): correlation of representative upper Cretaceous-Eocene sections using two datums: $\mathrm{X}$ - lower-upper Maastrichtian boundary; Y - Cretaceous-Paleogene boundary. Note that PETM clays drape the channel walls (Trabakua pass west and Balcón de Bizkaia sections) and the basin floor (Trabakua pass east section).

Pujalte et al., 1994; Baceta, 1996). Accordingly, the excavation of the channel appears to have been initiated in early Danian times.

The deep-sea channel persisted as a prominent feature of the Basque Basin until the earliest Eocene, when it was buried by the Eocene flysch (Figs. 7, 8). The channel had a dominantly erosive character, acting essentially as a conduit for high-concentration turbiditic currents, while hemipelagic sedimentation continued on the channel walls and outside the channel. Consequently, three different types of Paleocene sedimentary successions are recognized in the Basque Basin, namely basin floor, channel-wall and channel-bottom associations (Figs. 7, 8). The first two are largely made up of stacks of hemipelagic limestones and marls. However, while suc- cessions of the basin floor (typified by the Zumaia section) are continuous and up to $130 \mathrm{~m}$ thick, the thickness of successions of the channel wall becomes progressively reduced towards the channel axis due to internal hiatuses (e.g., the Balcón de Bizkaia and Trabakua pass west sections, Fig. 8). The channel-bottom association is largely composed of thickly bedded calciturbidites in its lower part and of thickly bedded siliciclastic turbidites in its upper part (Figs. 9a, 10a, b).

\subsubsection{The P-E interval at the Orio section}

Because of the scarce attention hitherto paid to the resedimented deposits of the deep-sea channel, no previous attempt had been made to pinpoint the PETM in them. The Orio section was chosen to alleviate this information gap for several 


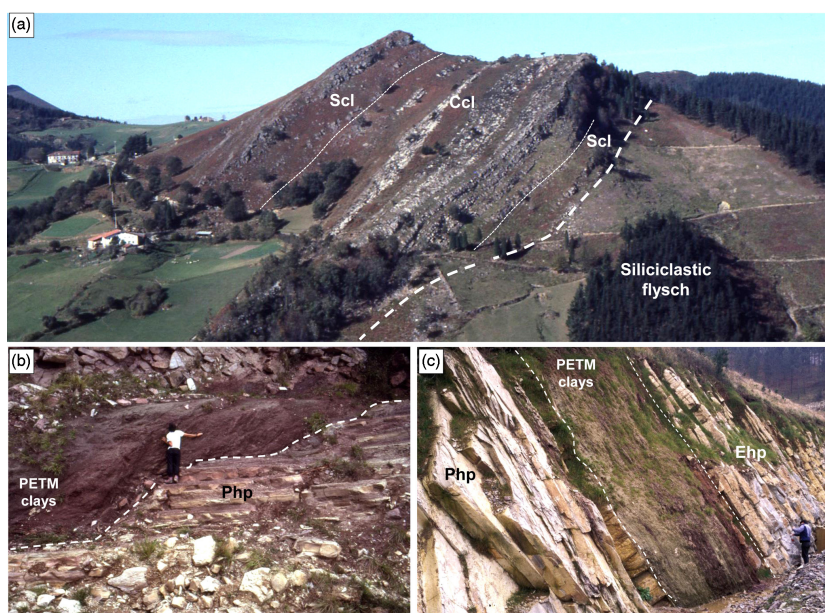

Figure 9. Field images of representative sections from the Gonzugaraia-Trabakua pass area (location in Fig. 8): (a) Gonzugaraia, deep-sea channel bottom; (b) Trabakua pass west, deep-sea channel wall; (c) Trabakua pass east, basin floor.

reasons: (i) it is the thickest section of these deposits available in the Basque Basin (Baceta, 1996); (ii) the age of its carbonate-dominated lower part is well constrained by microfossils (Fig. 7a', c); and, (iii) a recent enlargement of the road connecting the N-634 road with the highway has created a clean outcrop of the upper segment of the section, the target of this study, from which fresh samples could be collected (Fig. 10d). The location of the section is shown in Fig. $7 \mathrm{~b}$, with the studied segment situated at $43^{\circ} 16^{\prime} 50^{\prime \prime} \mathrm{N}$, $2^{\circ} 06^{\prime} 52^{\prime \prime} \mathrm{W}$.

The target segment is placed well above Thanetian calciturbidites of the NP7/8 Zone and below deposits of the Eocene calciclastic-siliciclastic flysch containing Tribrachiatus contortus (NP 10, Fig. 7a'). This nannofossil species (renamed Rhomboaster contortus in some more recent papers) slightly postdates the PETM (Aubry, 1996), its lower occurrence at Zumaia being located $5 \mathrm{~m}$ above the top of the PETM (Orue-Etxebarria et al., 2004). The target segment is exclusively made up of siliciclastic deposits, but two different parts are readily identified (parts $\mathrm{Y}$ and $\mathrm{Z}$ in Figs. 10d, 11). Part $\mathrm{Y}$ is composed of plane-parallel sandy turbidites, $0.5-1 \mathrm{~m}$ thick, separated by laterally continuous $1-2 \mathrm{~cm}$ thick clay interbeds (white arrows in Fig. 10d). The sandstones are medium-grained and loosely cemented, probably due to decalcification. Thin sections reveal that, in addition to quartz, they contain around 5-7\% of feldspars, rock fragments and micas, as well as a small proportion of matrix.

Part $\mathrm{Z}$ is composed of amalgamated sandstones and pebbly sandstones, the latter with clasts up to $3 \mathrm{~cm}$ in diameter (Fig. 10g). They occur in beds ranging $2-4 \mathrm{~m}$ in thickness, often separated by concave-up erosional surfaces, the thickest bed occurring at the top of part Z, just below the Eocene flysch (Supplement Fig. S2a, b). Most beds have
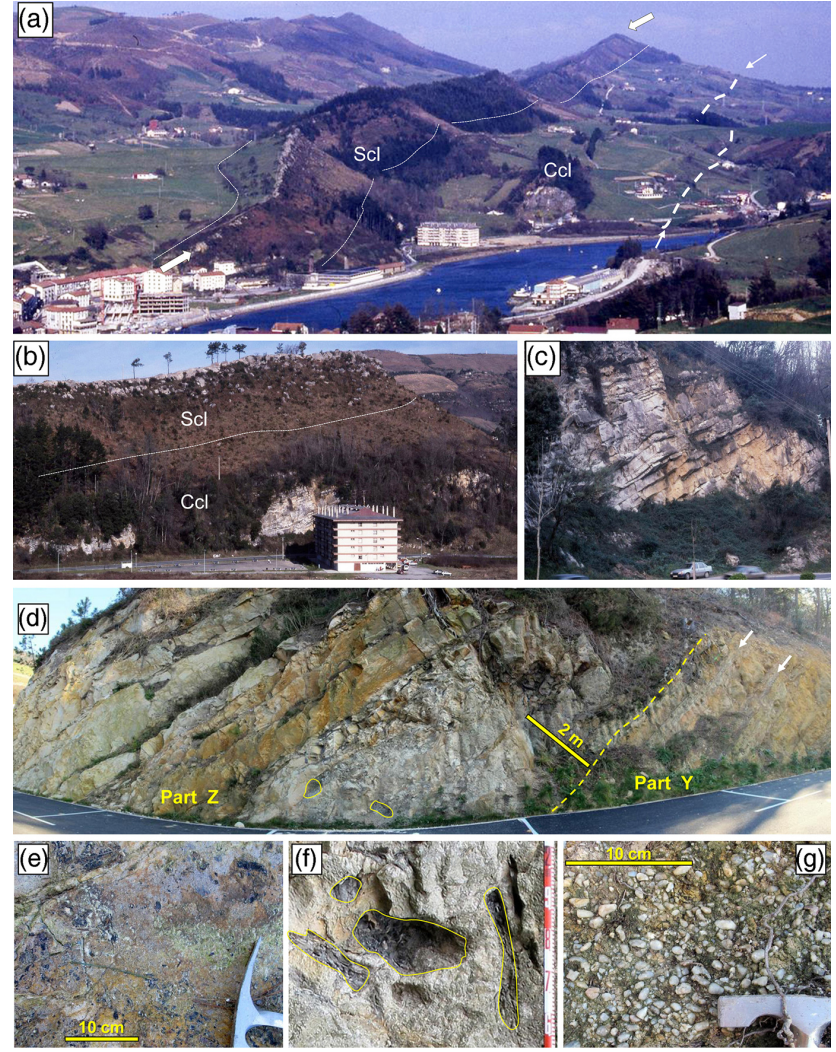

Figure 10. Panel (a): general view of deep-sea channel deposits to the east of Orio (village at the bottom left corner of the image): the thick broken white line and small white arrows indicate the base of the deep-sea channel succession; the big white arrows point to the prominent ridge created by the PETM quartzarenites; $\mathrm{Ccl}$ and $\mathrm{Scl}$, parts of the succession respectively dominated by calciclastic and siliciclastic deposits. Panels $(\mathbf{b}, \mathbf{c})$ : general view and close-up of $\mathrm{Ccl}$ deposits in quarries near the N-634 road; panel (d): field view of the studied upper part of the Scl-dominated succession illustrating the different aspect of parts $\mathrm{Y}$ and $\mathrm{Z}$; the white arrows in part Y designate thin clay interbeds. Panels (e-f): close-ups of the quartzarenites of part $\mathrm{Z}$, showing coal remains on the top surface of a bed, clay clasts and a pebbly accumulation (for additional features of part Z see Supplement Fig. S2).

a massive appearance, but some are clearly parallel laminated throughout, including the topmost one (Supplement Fig. S2c). Some of the bedding surfaces are strewn with coal remains (Fig. 10e). The sandstones are almost exclusively composed (>95\%) of quartz grains, with only traces of micas and rock fragments, and are pervasively cemented by quartz. Part $\mathrm{Z}$ is therefore very resistant to erosion, creating a prominent ridge in the landscape (Fig. 10a, b). Clay interbeds are rare, thin and discontinuous. However, clay clasts up to $30 \mathrm{~cm}$ in diameter are common in some levels (Fig. 10d, f). These clasts are considered the eroded remnants of coeval mud deposits, as their originally soft nature implies minimum transport. 

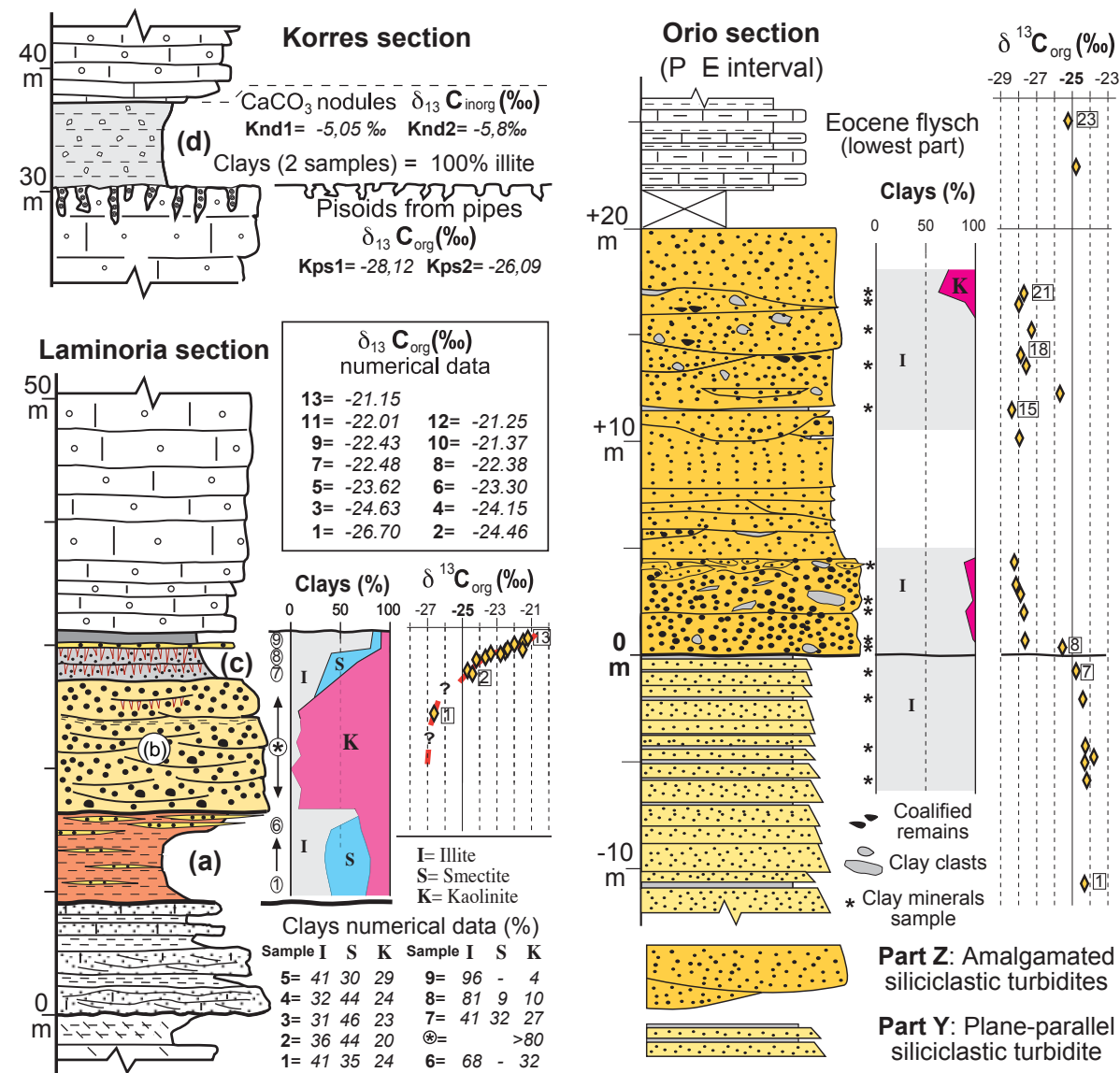

Figure 11. Clay mineral and $\mathrm{C}$ stable isotope profiles across the $\mathrm{P}-\mathrm{E}$ interval of the Korres, Laminoria and Orio sections. The $\mathrm{C}$ isotope data from the Orio section are also listed in Table 1. Biostratigraphic data for the Korres and Laminoria sections are given in Fig. 4 and for the Orio section in Fig. 7.

\subsection{Stable isotope and clay mineral data from Laminoria and Korres}

Samples from terrestrial units A, B and C were collected at the Laminoria section; samples from unit $\mathrm{D}$, and from pisoids, were collected at the Korres section. The clay mineralogy of units A, B and C was investigated in nine samples, that of unit $\mathrm{D}$ in two samples. Organic carbon isotopes from units $\mathrm{B}$ and $\mathrm{C}$ were investigated in 13 clay samples and from 2 samples of pisoids. Inorganic carbon isotopes were analyzed in two carbonate nodule samples of unit $\mathrm{D}$. The results are shown in Fig. 11.

The six clay samples from unit A contain illite, smectite and kaolinite, the proportion of the latter ranging between 20 and $32 \%$. Routine analyses of the clay matrix of unit B sands always produce high kaolinite contents (80-100\%; J. R. Subijana, personal communication, March 2015). Illite, smectite and kaolinite also occur in the three samples of unit $\mathrm{C}$, the proportion of kaolinite steadily decreasing upwards, from $27 \%$ in sample 7 to just $4 \%$ in sample 9 . The two samples from unit D exclusively contain illite.
No fresh samples for isotopic analysis could be recovered from unit A. Only one fine-grained sample was collected from unit $\mathrm{B}$, which produced a rather negative isotopic value $\left(-26.7 \%\right.$ o $\left.\delta^{13} \mathrm{C}_{\text {org }}\right)$. The 11 samples from the overlying unit $\mathrm{C}$ reveal a steady vertical trend towards less negative $\delta^{13} \mathrm{C}_{\mathrm{org}}$ values, from $-24.5 \%$ in sample 3 to $-21.2 \%$ in sample 13 (Fig. 11). The two pisoid samples from Korres yielded low $\delta^{13} \mathrm{C}_{\text {org }}$ values $(-28.1$ and $-26.1 \%$ ), while the soil nodules from unit $\mathrm{D}$ yielded -5.1 and $-5.8 \% \circ \delta^{13} \mathrm{C}_{\text {inorg }}$ values (Fig. 11).

\subsection{Stable isotope and clay mineral data from the Orio section}

All samples from part $\mathrm{Y}$ of the studied segment at Orio were collected from thin clay interbeds. Most samples from part Z were collected from either clay interbeds or from clay clasts, but one sample of coal remains was also taken. Fourteen of these samples were analyzed for clay minerals and 23 for organic carbon isotopes. Two marl samples of the Eocene flysch were investigated for organic carbon. The location of 
the samples and the analytical results are plotted in Fig. 11, and the isotopic data are also listed in Table 1.

The clay fraction of samples from part $\mathrm{Y}$ is exclusively made up of illite. This mineral is also dominant in the samples from part Z. However, small concentrations of kaolinite $(2-18 \%)$ were found in 6 out of the 10 samples analyzed (Fig. 11).

The $\delta^{13} \mathrm{C}_{\text {org }}$ composition of the seven samples analyzed from part $\mathrm{Y}$ shows a stable vertical trend, with values ranging from -24.2 to $-24.8 \%$, averaging out at $-24.3 \%$ o. Values from the 21 samples analyzed from part $\mathrm{Z}$ range from -25.5 to $-28.3 \%$ and average out at $-27.6 \%$, as most values lie in the lower end of the range (Table 1). These data include a drop of $-3.3 \%$ in carbon isotope values. The $\delta^{13} \mathrm{C}_{\text {org }}$ values return to -24.8 and $-25.4 \%$ in the basal part of the overlying Eocene flysch (Fig. 11).

\section{Discussion}

\subsection{Age models}

Biostratigraphic data from sections in the SE Pyrenees, Egypt and Slovenia demonstrate that the PETM occurred at the base of the SBZ-5 biozone (e.g., Orue-Etxebarria et al., 2001; Pujalte et al., 2003a, 2009; Scheibner et al., 2005; Zamagni, 2012; Drobne, 2014). In the Campo section, in particular, the thermal event is recorded within terrestrial deposits from the lower part of DS Il-1 (Fig. 2; Schmitz and Pujalte, 2003; Baceta et al., 2011). It is also well established that the PETM is located around the NP9-NP10 boundary in open marine successions (e.g., Monechi et al., 2000; OrueEtxebarria et al., 2004). It is thus reasonable to suppose that the PETM may be recorded within some of the terrestrial units A to D of Laminoria and Korres and within the siliciclastic turbidites of the upper part of the deep-sea channel succession of Orio. Neither the terrestrial units, nor the siliciclastic turbidites, contain fossils of chronostratigraphic significance. Therefore, carbon isotopes and clay minerals have been used to try to constrain the position of the thermal event.

A pulse of kaolinite accumulation in connection with the PETM has been documented in widely separated sections around or in the Atlantic Ocean, including the Bass River on the USA east coast (Gibson et al., 2000; John et al., 2012), Site 690 in the southern Atlantic (e.g., Shackleton and Hall, 1990), the Paris Basin (e.g., Thiry and Dupuis, 1998, 2000; Quesnel et al., 2011), the Svalbard archipelago (Dypvik et al., 2011) or Zumaia and Ermua in the Basque Basin (Fig. 2; Knox, 1998; Bolle et al., 1998). At Zumaia kaolinite first appears in significant amounts (up to $25 \%$ of the clay mineral assemblage) some $10 \mathrm{~m}$ below the onset of the PETM, the proportion increasing sharply (up to $75 \%$ ) at the onset of the thermal event (Knox, 1998). The origin of the pulse is controversial (e.g., John et al., 2012, and below), but, together with carbon isotope data, it is used here to establish an age model for clastic units A-D of Laminoria and Korres.
The highest content of kaolinite occurs in unit B at Laminoria, which is accordingly tentatively assigned to the core of the PETM. The isotopic value of the sample from this unit $\left(-26.7 \% \circ \delta^{13} \mathrm{C}_{\mathrm{org}}\right)$ is fully compatible with that proposal (Fig. 11). Indeed, analyses of well-constrained P-E terrestrial and marine sections elsewhere in the Pyrenees concur in that the PETM interval is characterized by $\delta^{13} \mathrm{C}_{\text {org }}$ isotopic values ranging from -26.0 to $-28.8 \%$, while pre- and postPETM background values vary between -22.0 and $-25.0 \%$ (e.g., Storme et al., 2012; Manners et al., 2013; Pujalte et al., 2014a). The proportion of kaolinite in unit $\mathrm{C}$ decreases upward, in parallel with a steady trend towards less negative $\delta^{13} \mathrm{C}_{\mathrm{org}}$ values (Fig. 11). Both sets of data are strongly indicative that unit $\mathrm{C}$ was accumulated, totally or in part, during the recovery phase of the PETM, further reinforcing the ascription of unit B to the PETM. The age of unit A is less well constrained because no samples suitable for isotopic analysis could be obtained. However, a pre-PETM age is suggested by its comparatively low content of kaolinite and by its stratigraphic position below unit B (Fig. 11).

The pisoids enclosed in the pipes at the top of the DS TH-2 at the Korres section yielded typical PETM $\delta^{13} \mathrm{C}_{\text {org }}$ isotopic values $(-26.1$ and $-28.1 \%$; Fig. 11). Such values imply that the marine deposits of this depositional sequence were subaerially exposed during the thermal event. The absence of

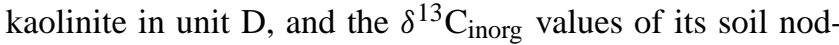
ules $(-5.1$ and $-5.8 \%$ ), indicate a post-PETM age.

The isotope results from the Orio deep-sea channel deposits are even more conclusive. In effect, the $-3.3 \%$ shift in $\delta^{13} \mathrm{C}_{\text {org }}$ observed from part $\mathrm{Y}$ to part $\mathrm{Z}$ of the studied segment can only correspond to the PETM, for no other CIE of such magnitude is known to occur in the interval between the calcareous nannofossil zone NP7/8 and the lowest occurrence of the species $T$. (R.) contortus (lower part of NP 10). Consequently, the amalgamated coarse-grained deposits of part $\mathrm{Z}$ are confidently assigned to the PETM. The clay mineral results from Orio are somewhat ambiguous, as kaolinite only occurs in some of the samples from part $\mathrm{Z}$, and then only in low proportions. It should be noted, however, that the PETM kaolinite influx is very variable, and locally absent, in some basins (e.g., in the Paris Basin; Thiry and Dupuis, 1998; Quesnel et al., 2011).

\subsection{Evolution of the incised valleys across the P-E interval}

It is widely acknowledged that incised valleys in marine basin margins are usually excavated during relative sea-level falls and filled with sediments during the subsequent sealevel rise (e.g., Boyd et al., 2006; Strong and Paola, 2008). The subaerial exposure of the marine carbonates of the DS TH-2 at Korres and elsewhere in the Pyrenees (e.g, in the Campo section, Fig. 2) is clear proof of a sea-level fall, which in all probability triggered the incision of the valleys. The oldest unit of the valley-fill succession (unit A of Laminoria) 


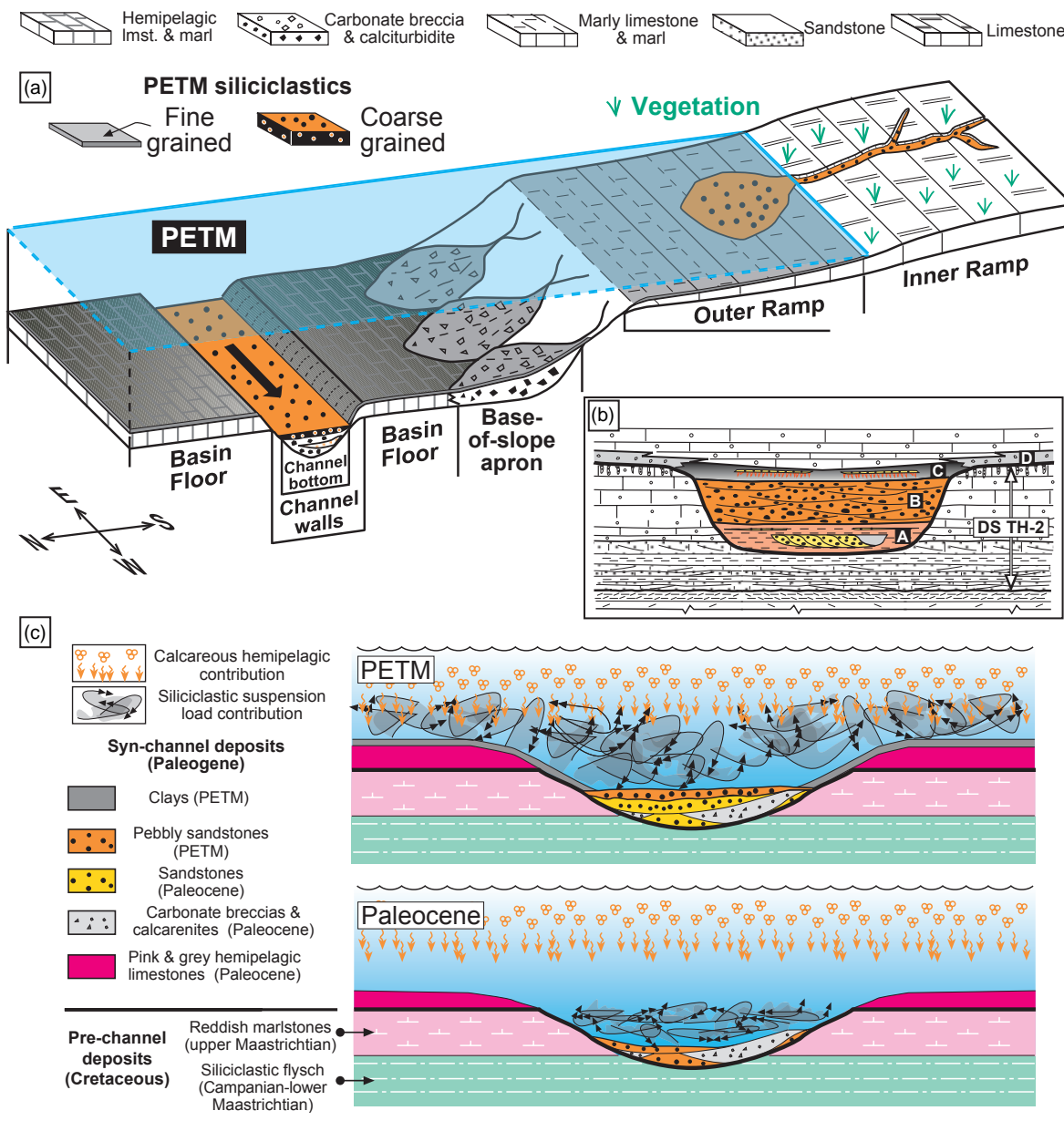

Figure 12. Panel (a): reconstructed S-N transects of the southwestern margin of Pyrenean Gulf for PETM times: most of the gulf floor was mantled with fine-grained siliciclastics; however, coarse-grained sands and pebbly sands were also accumulated within incised valleys, deltas and a deep-sea channel. Panel (b): reconstructed architecture of the incised valleys. Panel (c): graphic models depicting the depositional conditions in the Basque Basin: throughout Paleocene times clastic loads were largely confined to the deep-sea channel, while hemipelagic deposition occurred on the basin floor. During the PETM clastic input increased dramatically: coarse-grained bed load remained confined to the deep-sea channel bottom but suspension load became widespread, blanketing the channel walls and diluting hemipelagic sedimentation on the basin floor.

is pre-PETM, which means that the excavation of valleys was prior to the onset of the PETM. Filling of the valleys during the sea-level rise occurred in three phases, recorded by units A, B and C (Figs. 11, 12). These three units are considered terrestrial in origin, based on the absence of marine fossils and the presence of root marks. However, their contrasting lithologies and sedimentary features are indicative of different depositional conditions.

Unit A was accumulated in a low-energy setting, probably a flood plain, as demonstrated by the predominance of clays. The intercalated rippled sandstone lenses are probably distal crevasse splay deposits. Flood plains are best developed in meandering river systems, and we speculate that point bar channel sands do actually exist in unit A. The red color of the clays implies well-drained and oxidized soils. The absence of calcite nodules suggests that either soil moisture was too high or that the accumulation of clays was too rapid for nodules to form.

The sedimentary features of unit B imply a drastic change in depositional conditions during the PETM. Indeed, the prevalence of sands and pebbly sands required a much greater stream power than in the underlying unit A. Furthermore, the scarcity of fine-grained deposits coupled with the large-scale trough cross-bedding or channeling in the pebbly sands indicate a braided river system stretching across most, if not all, the width of the incised valleys.

The vertical reduction in grain size in unit $\mathrm{C}$ likely records the backstepping and ponding of the fluvial system as the sealevel rise continued during the recovery phase of the PETM. Indeed, the widespread hematite-coated root traces in subunit $\mathrm{C} 1$ suggest wet soil conditions, and the preservation of abundant coal remains in subunit $\mathrm{C} 2$ is indicative of a water- 
logged environment. The rise in sea level eventually caused the marine flooding of the valleys, attested by the deposition of the Alveolina limestones above unit $\mathrm{C}$ in the Laminoria and Villalain incised valleys (Fig. 6d, f). The post-PETM age assigned to unit $\mathrm{D}$ at Korres denotes a small time lag in the reestablishment of fully marine conditions outside the valleys (Fig. 3).

\subsection{Changes in the deep-sea channel across the P-E interval}

The contrasting sedimentary features of parts $\mathrm{Y}$ and $\mathrm{Z}$ of the Orio section denote an abrupt change in depositional conditions. The tabular geometry and the massive character of the sandstone beds of part Y, and the fact that many of them are capped by thin but laterally persistent clay deposits, suggest deposition from waning high-density currents (Figs. 10d and 11). By contrast, several features of part $Z$ deposits are best explained by deposition from hyperpycnal flows generated by direct river effluents (cf. Plink-Björklund and Steel, 2004). For instance, the $4 \mathrm{~m}$ thick topmost bed of part $\mathrm{Z}$ is parallel laminated throughout (Supplement Fig. S2a, c), a strong indication of a sustained upper flow regime. Although internal erosional surfaces preclude establishing the original bed thicknesses in the bulk of part Z, it is reasonable to assume that many of the strata most likely had a similar thickness and character as the topmost $4 \mathrm{~m}$ thick bed (Supplement Fig. S2b). The abundant coal remains of obvious terrestrial derivation (Fig. 10e) are another clear indication of direct river input.

Flood events can produce both hypopycnal and hyperpycnal flows at river mouths (e.g., McLeod et al., 1999). Decoupling of coarse- and fine-grain populations due to the separation of both flows is relatively common (e.g., PlinkBjörklund and Steel, 2004). This process may explain the simultaneous deposition of sandstone-dominated beds in the bottom of the deep-sea channel and of clays in the channel walls during the PETM (Figs. 7-9).

\subsection{The PETM kaolinite influx}

The origin of the increased kaolinite flux during the PETM is somewhat controversial, some authors arguing in favor of enhanced chemical weathering (e.g., Bolle and Adatte, 2001; Gibson et al., 2000; Dypvik et al., 2011) but others supporting enhanced erosion of former kaolinite-rich soils (e.g., Thiry and Dupuis, 2000; John et al., 2012).

In the study area kaolinite has been found in the three terrestrial units of the Laminoria incised valley, the highest percentage occurring in unit B (Fig. 11). These terrestrial units probably had their source in the Hercynian Ebro Massif (Fig. 1), now buried under thick Oligocene-Miocene alluvial deposits of the Ebro foreland basin (Lanaja and Navarro, 1987). Similar Hercynian basement rocks are extensively exposed further south, where they commonly appear capped by an up to $50 \mathrm{~m}$ thick lateritic profile, attributed to prolonged pedogenesis under prevailing humid tropical conditions during the Cretaceous (Molina Ballesteros, 1991). The lateritic profile is overlain by the "Siderolithic Series", an extensive lower Paleogene alluvial unit (Santisteban Navarro et al., 1991; Molina Ballesteros et al., 2007). The main components of the conglomerates, sandstones and overbank fines of the "Siderolithic Series" are quartz and kaolinite, derived from the erosion of the lateritic profile. Moreover, the conglomerates and sandstones are cemented by silica and contain significant amounts of $\mathrm{Fe}$ oxyhydroxides, from which the name of the unit was coined. By analogy, the quartz-rich nature and high content of kaolinite and hematite in unit B at Laminoria, strongly suggest that it also resulted from the erosion of a similar lateritic profile developed on the Ebro Massif. Therefore, the kaolinite spike in this unit is best explained by enhanced erosion rather than by intensified chemical weathering during the PETM.

Kaolinite occurs at concentrations of 6-8\% throughout most of the Paleocene terrestrial deposits of the Tremp Basin, increasing to up to $15 \%$ during the PETM (Schmitz and Pujalte, 2003). However, paleosols across the entire P-E interval indicate a semiarid climate, further suggesting that their kaolinite content did not result from coeval chemical weathering (Schmitz and Pujalte, 2003). The terrestrial deposits of Tremp were mainly eroded from Cretaceous marine carbonate rocks uplifted during a Santonian-Campanian tectonic phase in the eastern Pyrenees (Fig. 1). No significant alteration profile is known for these uplifted carbonates, a fact that in all probability explains the comparatively low kaolinite content in the resulting alluvium.

The proportion of kaolinite in marine PETM units of the Basque Basin ranges from up to $75 \%$ in Zumaia to $18 \%$ or less in Ermua and Orio (Figs. 2 and 11). Such variability is thought to record a mixed contribution from different source areas (Fig. 1).

\subsection{The PETM hydrologic change}

The PETM coarse-grained siliciclastics of unit B in the incised valleys and of part $\mathrm{Z}$ in the deep-sea channel are proof of large increases in, respectively, stream power (which requires greater discharges) and strength and capacity of turbidity currents. PETM coarse-grained sands were also accumulated in a fan delta in the south-central Pyrenees (Fig. 12a, Pujalte et al., 2014b). To evaluate the significance of this influx, however, it must be taken into account that the volume of fine-grained siliciclastics delivered to the Pyrenean Gulf during the PETM far exceeded that of sands and pebbly sands. As a result, a mud blanket $3 \mathrm{~m}$ thick on average (after compaction) covered most of the outer platform (Pujalte et al., 2003a), the base-of-slope apron (Schmitz et al., 2001), the basin floor (Schmitz et al., 1997; Baceta, 1996) and, more remarkably, the deep-sea channel walls (Figs. 8b, 9b, c). 
The most plausible explanation of the abrupt increase in both coarse- and fine-grained clastic input to the Pyrenean Gulf during the PETM is a rapid enhancement of seasonal precipitation extremes in an overall dry environment. In effect, it is well established that in semiarid areas intraannual variations in precipitation rates are strong and that, during flood events, suspended sediment concentrations in rivers are very high. For example, data compiled from the semiarid Carapelle watershed in southern Italy (Bisantino et al., 2011, their Table 3) show that the concentration of suspended sediments in the Carapelle torrent during intense flood events is as high as $43 \mathrm{~g} \mathrm{~L}^{-1}$. Even higher suspension load concentrations $\left(250 \mathrm{~g} \mathrm{~L}^{-1}\right)$ have been measured in the Wadi Wahrane of Algeria during flood events (Benkhaled and Remini, 2003).

Semiarid to arid climates prevailed during Paleocene times in the Pyrenean Gulf, as demonstrated by paleosols rich in calcareous nodules and gypsum in the terrestrial Tremp Group of the eastern Pyrenees (Schmitz and Pujalte, 2003). Accordingly, the rise in temperatures during the PETM, could have prolonged and intensified summer drought but increased the frequency and magnitude of cool-season flood events. This would have increased river channel competence and the volume of suspension loads.

The change in channel pattern recorded in the incised valleys, from meandering during the accumulation of unit $\mathrm{A}$ to braided during the accumulation of unit B (Fig. 12b), is congruent with the proposed hydrological change. The possibility that this change was caused by a tectonic event is highly unlikely, since tectonic quiescence prevailed in the Pyrenean domain throughout the latest Maastrichtian-middle Ilerdian interval (e.g., Fernández et al., 2012; Pujalte et al., 2014a). Furthermore, Bridge (2003) maintains that river channel patterns are determined by the type of flows at averaged bankfull discharges ("channel-forming discharge"), a configuration that is only slightly modified at low discharges. Bridge (2003, p. 155, his Fig. 5.9) also indicates that the width and depth and the degree of braiding of rivers increase as their channel-forming discharge increases. Thus, the observed change from a meandering to a braided pattern can reasonably be attributed to the higher frequency and magnitude of flood events during the PETM.

Changes recorded in the deep-sea channel can also be explained in the context of the PETM hydrological change. The deep-sea channel acted mainly as a conduit towards deeper water for turbidity currents reaching the axial part of the Basque Basin. During most of Paleocene times these currents mainly carried coarse clastics, either carbonate or siliciclastic, while channel walls were subjected to erosion and the basin floor mainly received hemipelagic sediments (Fig. 12c). Sedimentological evidence suggests that, during the PETM, hyperpycnal flows deposited coarse-grained sands and pebbly sands in the deep-sea channel bottom, while a larger fraction of fines carried by hypopycnal plumes were deposited on the channel walls and on the basin floor, greatly diluting the hemipelagic contribution (Fig. 12c).

\section{Conclusions}

The significant change in sedimentary conditions recorded in the western part of the Pyrenean Gulf across the P-E boundary interval can satisfactorily be explained by a dramatic and abrupt change in hydrology and a pre-PETM sea-level fall. During the PETM dry conditions were intensified or prolonged during the warm season, whereas precipitation events and flash floods became more intense during the cooler season. In a dry, vegetation-barren landscape, seasonal precipitation extremes effectively eroded the landscape. As a result, during rainy intervals fluvial currents carried large volumes of both coarser bed load and suspension load. Delivery of the increased sediment load to the marine basin was facilitated by the low position of the sea level. A fraction of the bed load was accumulated within incised valleys, which had been excavated during a pre-PETM sea-level fall, and on a fan delta at a valley mouth. The remainder of the coarsegrained fraction, transported by hyperpycnal flows, reached a deep-sea channel excavated along the axial part of the Basque Basin. Deposition of the suspension load was much more widespread, covering much, if not all, of the outer platform, the base-of-slope, the basin floor and even the walls of the deep-sea channel. This implies that the rivers transported and delivered a much larger volume of fine-grained sediments than of coarse-grained sediments, another indication of precipitation extremes. The influx of kaolinite during the PETM, probably due to the intensified erosion of Cretaceous lateritic profiles developed on the Hercynian basement, is also attributable to enhanced seasonal precipitation.

Based on an entirely different set of data from the Tremp Basin, in the eastern Pyrenees, a similar hydrological change was proposed by Schmitz and Pujalte (2007). The data from the western Pyrenees here presented reinforce such a proposal and indicate that the hydrological change affected the entire Pyrenean domain.

\section{The Supplement related to this article is available online at doi:10.5194/cp-11-1653-2015-supplement.}

Acknowledgements. V. Pujalte and J. I. Baceta received funding from Research Project CLG2011-23770 (Ministerio de Economía y Competitividad, Spanish Government) and Research Group of the Basque University System, Basque Government, IT-631-13. B. Schmitz received funding from the Swedish Research Council (LUCCI Linné Grant). Advice provided by Gilen Bernaola on the calcareous nannofossil data of van Vliet is greatly appreciated. We are grateful to María Lema Grille for the isotope analyses and Javier Sangüesa for the X-ray analyses. Thanks are extended to 
Juan Echave and to Jose Ramón Subijana, owner and geologist of the sand quarries, for granting permission to visit and sample the Laminoria and Villalain quarries and for information about the composition of the sands. The suggestions of referees F. Quesnel and B. S. Slotnick, and of journal editor G. R. Dickens, greatly helped to improve this paper.

Edited by: G. Dickens

\section{References}

Adatte, T., Bolle, M. P., de Kaenel, E., Gawenda, P., Winkler, W., and von Salis, K.: Climatic evolution from Paleocene to earliest Eocene inferred from clay-minerals: a transect from northern Spain (Zumaya) to southern (Spain, Tunisia) and southeastern Tethys margins (Israel, Negev), GFF, 122, 7-8, 2000.

Alegret, L., Ortiz, S., Orue-Exteberria, X., Bernaola, G., Baceta, J.I., Monechi, S., Apellaniz, E., and Pujalte, V.: The PaleoceneEocene thermal maximum: new data on microfossil turnover at the Zumaia section, Spain, Palaios, 24, 318-328, 2009.

Allan, R. P. and Soden, B. J.: Atmospheric warming and the amplification of precipitation extremes, Science, 321, 1481-1484, 2008.

Allen, J. R. L.: Studies in fluviatile sedimentation: bars, bar complexes and sandstone sheets (low-sinuosity braided stream) in the Brownstones (L. Devonian), Sedim. Geol., 33, 237-293, 1983.

Aubry, M. P.: Towards an upper Paleocene-lower Eocene high resolution stratigraphy, in: Paleocene/Eocene Boundary Events in Space and Time, edited by: Aubry, M. P. and Benjamini, C., Israel Journal of Earth Sciences, 44, 239-253, 1996.

Baceta, J. I.: El Maastrichtiense superior, Paleoceno e Ilerdiense inferior de la Región Vasco-Cantábrica: secuencias deposicionales, facies y evolución paleogeográfica, $\mathrm{PhD}$ thesis, University of the Basque Country, 372 pp., 1996.

Baceta, J. I., Pujalte, V., Robles, S., and Orue-Etxebarria, X.: Influencia del diapiro de Zarautz sobre los procesos de resedimentación Paleocenos de Orio (Guipúzcoa, Cuenca Vasca), Geogaceta, 9, 57-60, 1991.

Baceta, J. I., Pujalte, V., and Payros, A.: Rellenos de valles encajados en el Maastrichtiense superior y Paleógeno inferior de Alava (Plataforma Noribérica, Cuenca Vasca), Geogaceta, 16, 86-89, 1994.

Baceta, J. I., Pujalte, V., Dinarès-Turell, J., Payros, A., OrueEtxebarria, X., and Bernaola, G.: The Paleocene/Eocene boundary interval in the Zumaia Section (Gipuzkoa, Basque Basin): Magnetostratigraphy, and high-resolution lithostratigraphy, Revista de la Sociedad Geológica de España, 13, 375-391, 2000.

Baceta, J. I., Pujalte, V., Serra-Kiel, J., Robador, A., and OrueEtxebarria, X.: El Maastrichtiense final, Paleoceno e Ilerdiense inferior de la Cordillera Pirenaica, in: Geología de España, edited by: Vera, J. A., Sociedad Geológica de España-Instituto Geológico y Minero de España, Madrid, 308-313, 2004.

Baceta, J. I., Pujalte, V., Wright, V. P., and Schmitz, B.: Carbonate platform models, sea-level changes and extreme climatic events during the Paleocene-early Eocene greenhouse interval: a basin-platform-coastal plain transect across the southern Pyrenean basin, in: Pre-Meeting Field-Trips Guidebook, edited by: Arenas, C., Pomar, L., and Colombo, F., 28th IAS Meeting,
Zaragoza, Sociedad Geológica de España, Geo-Guías, 7, 101150, 2011.

Beniston, M., Stephenson, D. B., Christensen, O. B., Ferro, C. A. T., Frei, C., Goyette, S., Halsnaes, K., Halt, T., Jylhä, K., Koffi, B., Palutkof, J., Schóll, R., Semmler, T., and Woth, K. Future extreme events in European climate: an exploration of regional climate model projections, Climate Change, 81, 71-95, 2007

Benkhaled, A. and Remini, B.: Temporal variability of sediment concentration and hysteresis phenomena in the Wadi Wahrane basin, Algeria, Hydrol. Sci. J., 48, 243-255, 2003.

Berg, N. and Hall, A.: Increased interannual precipitation extremes over California under climate change, J. Climate, 28, 6324-6334, 2015.

Berggren, W. A. and Aubry, M.-P.: The Paleocene/Eocene Epoch/Series Boundary: Chronostratigraphic Framework and Estimated Geochronology, in: Late Paleocene-Early Eocene Climatic and Biotic Events in the Marine and Terrestrial Records, edited by: Aubry, M.-P., Lucas, S., and Berggren, W. A., Columbia University Press, New York, 18-36, 1998.

Berggren, W. A., Kent, D. V., Swisher III, C. C., and Aubry, M. P.: A revised Cenozoic geochronology and chronostratigraphy, in: Geochronology, time scales and global stratigraphic correlations, edited by: Berggren, W. A., Kent, D. V., Aubry, M. P., and Hardenbol, J., S.E.P.M. Spec. Publ., 54, 129-212, 1995.

Bisantino, T., Gentile, F., and Liuzzi, G. T.: Continuous Monitoring of Suspended Sediment Load in Semi-arid Environments, edited by: Ginsberg S. S., Sediment Transport, 295-312, InTech Europe, University Campus STeP Ri, Slavka Krautzeka 83/A, 51000 Rijeka, Croatia, 2011.

Bolle, M. P. and Adatte, T.: Palaeocene-early Eocene climatic evolution in the Tethyan realm: Clay mineral evidence, Clay Minerals, 36, 249-261, 2001.

Bolle, M. P., Adatte, T., Keller, G., von Salis, K., and Hunziker, J.: Biostratigraphy, mineralogy and geochemistry of the Trabakua Pass and Ermua sections in Spain, Eclog. Geol. Helv., 91, 1-25, 1998.

Bowen, G. J., Koch, P. L., Gingerich, P. D., Norris, R. D., Bains, S., and Corfield, R. M.: Refined isotope stratigraphy across the continental Paleocene-Eocene boundary on Polecat Bench in the northern Bighorn Basin, in: Paleocene-Eocene Stratigraphy and Biotic Change in the Bighorn and Clarks Fork Basins, Wyoming, edited by: Gingerich, P. D., University of Michigan Papers on Paleontology, 73-88, 2001.

Boyd, R., Dalrymple, R. W., and Zaitlin, B. A.: Estuarine and Incised-Valley Facies Models, in: Facies Models Revisited, edited by: Posamentier, H. W. and Walker, R. G., SEPM Sp. Pub., 84, 171-235, 2006.

Bridge, J. S.: Rivers and Flood plains, Forms, Processes, and Sedimentary record, Blackwell Publishing, 491 pp., 2003.

Calvet, F. and Julià, R.: Pisoids in the caliche profiles of Tarragona, north east Spain, in: Coated Grains, edited by: Peryt, T. M., Springer-Verlag, Berlin, 456-473, 1983.

Carter, R. M.: The nature and evolution of deep-sea channel systems, Basin Research, 1, 41-54, 1988.

Clare, M. A., Talling, P. J., and Hunt, J. E.: Implications of reduced turbidity current and landslide activity for the Initial Eocene Thermal Maximum - evidence from two distal, deep-water sites, Earth Planet. Sci. Lett., 420, 102-115, 2015. 
Dickens, G. R., O’Neil, J. R., Rea, D. K., and Owen, R. M.: Dissociation of oceanic methane hydrate as a cause of the carbon isotope excursion at the end of the Paleocene, Paleoceanography, 10, 965-971, 1995.

Dickens, G. R., Castillo, M. M., and Walker, J. C. G.: A blast of gas in the latest Paleocene: Simulating first-order effects of massive dissociation of oceanic methane hydrate, Geology, 25, 259-262, 1997.

Dinarès-Turell, J., Baceta, J. I., Pujalte, V., Orue-Etxebarria, X., and Bernaola, G.: Magnetostratigraphic and cyclostratigraphic calibration of a prospective Paleocene / Eocene stratotype at Zumaia (Basque Basin, northern Spain), Terra Nova, 14, 371-378, 2002.

Dinarès-Turell, J., Westerhold, T., Pujalte, V., Röhl, U., and Kroon, D.: Astronomical calibration of the Danian stage (Early Paleocene) revisited: Settling chronologies of sedimentary records across the Atlantic and Pacific Oceans, Earth Planet. Sci. Lett., 405, 119-131, 2014.

Drobne, K., Jez, J., Cosovic, V., Ogorelec, B., Stenni, B., Zakrevskaya, E., and Hottinger, L.: Identification of the Palaeocene-Eocene Boundary based on Larger Foraminifers in deposits of the Palaeogene Adriatic Carbonate Platform, Southwestern, Slovenia, in: STRATI 2013, edited by: Rocha, R., Pais, J., Kullberg J. C., and Finney, S., Springer International Publishing Switzerland, 89-93, 2014.

Dypvik, H., Riber, L., Burca, F., Rüther, D., Jargvoll, D., Nagy, J., and Jochmann, M.: The Paleocene-Eocene thermal maximum (PETM) in Svalbard - clay mineral and geochemical signals, Palaeogeogr. Palaeoecol. Palaeoclimatol., 302, 156-169, 2011.

Fernández, O., Muñoz, J. A., Arbués, P., and Falivene, O.: 3D structure and evolution of an oblique system of relaying folds: the Ainsa basin (Spanish Pyrenees), J. Geol. Soc. London, 169, 545559, 2012.

Foreman, B. Z.: Climate-driven generation of a fluvial sheet sand body at the Paleocene-Eocene boundary in nrth-west Wyoming (USA), Basin Res., 26, 225-241, 2014.

Foreman, B. Z., Heller, P. L., and Clementz, M. T.: Fluvial response to abrupt global warming at the Palaeocene/Eocene boundary, Nature, 491, 92-95, 2012.

Gibson, T. G., Bybell, L. M., and Mason, D. B.: Stratigraphic and climatic implications of clay mineral changes around the Paleocene/Eocene boundary of the northeastern US margin, Sedim. Geol., 134, 65-92, 2000.

Gómez de Llarena, J.: Observaciones en el Flysch CretácicoNummulítico de Guipúzcoa. Monografías Inst. Lucas Mallada, $13,1-98,1954$.

Handley, L., O’Halloran, A., Pearson, P. N., Hawkins, E., Nicholas, C. J., Schouten, S., McMillan, I. K., and Pancost, R. D.: Changes in the hydrological cycle in tropical East Africa during the Paleocene-Eocene Thermal Maximum, Palaeogeogr. Palaeoclimatol. Palaeoecol., 329-330, 10-21, 2012.

Hanisch, J. and Pflug, R.: The interstratified breccias and conglomerates in the Cretaceous Flysch of the northern Basque Pyrenees: submarine outflow of diapiric mass, Sedim. Geol., 12, 287-296, 1974.

Held, I. M. and Soden, B. J.: Robust responses of the hydrological cycle to global warming, J. Clim., 19, 5686-5699, 2006.

Hilgen, F. J., Abels, H. A., Kuiper, K. F., Lourens, L. J., and Wolthers, M.: Towards a stable astronomical time scale for the Paleocene: Aligning Shatsky Rise with the Zumaia-Walvis
Ridge ODP Site 1262 composite, Newsletter on Stratigraphy, 48, 91-110, 2015.

John, C. M., Banerjee, N, R., Longstaffe, F. J., Sica, C., Law, K. R., and Zachos, J. C.: Clay assemblage and oxygen isotopic constraints on the weathering response to the Paleocene-Eocene thermal maximum, east coast of North America, Geology, 40, 591594, 2012.

John, C. M., Bohaty, S. M., Zachos, J. C., Gibbs, S., Brinkhuis, H., Sluijs, A., and Bralower, T.: Impact of the Paleocene-Eocene thermal maximum on continental margins and implications for the carbon cycle in near-shore environments, Paleoceanography, 23, PA2217, doi:10.1029/2007PA001465, 2008.

Jones, B.: Biogenicity of terrestrial oncoids formed in soil pockets, Cayman Brac, British West Indies, Sedim. Geol., 236, 95-108, 2011.

Knox, R. W. O. B.: Kaolinite influx within Palaeocene/Eocene bounday strata of western Europe (Extended abstract), Newsletter on Stratigrahy, 36, 49-53, 1998.

Koch, P. L., Zachos, J. C., and Gingerich, P. D.: Correlation between isotope records in marine and continental carbon reservoirs near the Paleocene/Eocene boundary, Nature, 358, 319-322, 1992.

Kraus, M. J., McInerney, F. A., Wing, S. L., Secord, R., Baczynski, A. A., and Bloch, J. I: Paleohydrologic response to continental warming during the Paleocene-Eocene Thermal Maximum, Bighorn Basin, Wyoming. Palaeogeogr. Palaeoclimatol. Palaeoecol., 370, 196-208, 2013.

Kraus, M. J., Woody, D. T., Smith, J. J., and Dukic, V.: Alluvial response to the Paleocene-Eocene Thermal Maximum climatic event, Polecat Bench,Wyoming (U.S.A.), Palaeogeogr. Palaeoclimatol. Palaeoecol., 435, 177-192, 2015.

Lanaja, J. M. and Navarro, A.: Contribución de la exploración petrolífera al conocimiento de la Geología de España, Instituto Geológico y Minero de España., Madrid, 465 pp. 1987.

Le Callonnec, L., Renard, M., De Rafélis, M., Minoletti, F., Beltran, C., and Jan du Chêne, R.: Evolution of the trace element contents ( $\mathrm{Sr}$ and $\mathrm{Mn}$ ) of hemipelagic carbonates from the Zumaia Paleocene section (Gipuzkoa, Spain): implications for the knowledge of seawater chemistry during the Selandian, Bull. Soc. Géol. France, 185, 413-435, 2014.

Magioncalda, R., Dupuis, C., Smith, T., Steurbaut, E., and Gingerich, P. D.: Paleocene-Eocene carbon isotope excursion in organic carbon and pedogenic carbonate: Direct comparison in a continental stratigraphic section, Geology, 32, 553-556, 2004.

Manners, H. R., Grimes, S. T., Sutton,P. A., Domingo, L., Leng, M. J., Twitchett, R. J., Harta, M. B., Jones,T. D., Pancost, R. D., Duller, R., and López-Martínez, N.: Magnitude and profile of organic carbon isotope records from the Paleocene-Eocene Thermal Maximum: evidence from northern Spain, Earth Planet. Sci. Lett., 376, 220-230, 2013.

McInerney, F. A. and Wing, S. L.: The Paleocene Eocene Thermal Maximum: A Perturbation of Carbon Cycle, Climate, and Biosphere with Implications for the Future, Annu. Rev. Earth Planet. Sci., 39, 489-516, 2011.

McLeod, P., Carey, S., and Sparks, R. S. J.: Behaviour of particle laden flows into the ocean: experimental simulation and geological implications, Sedimentology 46, 523-537, 1999.

Molina Ballesteros, E.: Paleoalteraciones y evolución del relieve: el caso del Zócalo Hercínico Ibérico, in: Alteraciones y Paleoalteraciones en la morfología del oeste peninsular, edited by: 
Martín-Serrano, A., Molina Ballesteros, E., and Blanco, J. A., Instituto Geológico y Minero de España, Monografía, 4, 27-43, 1991.

Molina Ballesteros, E., Alonso Gavilán, G., and García Talegón, J.: Nuevas aportaciones al estudio del "siderolítico" (Fm. Areniscas de Salamanca). Borde Oeste de la Cuenca del Duero (Zamora), Geogaceta, 42, 27-30, 2007.

Monechi, S., Angori, E., and Speijer, R.: Upper Paleocene biostratigraphy in the Mediterranean region: Zonal markers, diachronism, and preservational problems, GFF, 122, 108-110, 2000.

Murphy, J. M., Sexton, D. M. H., Barnett, D. N., Jones, G. S., Webb, M. J., Collins, M., and Stainforth, D. A.: Quantification of modeling uncertainties in a large ensemble of climate change simulations, Nature, 430, 768-772, 2004.

Orue-Etxebarria, X., Apellaniz, E., Baceta, J. I., Coccioni, R., Di Leo, R., Dinarès-Turell, J., Galeotti, S., Monechi, S., NúñezBetelu, K., Parés, J. M., Payros, A., Pujalte, V., Samsó, J. M., Serra-Kiel, J., Schmitz, B., and Tosquella, J.: Physical and biostratigraphic analysis of two prospective Paleocene - Eocene Boundary stratotypes in the intermediate-deep water Basque Basin, western Pyrenees: The Trabakua Pass and Ermua sections, N. Jb. Geo. Palaont. Abh., 201, 179-242, 1996.

Orue-Etxebarria, X., Pujalte, V., Bernaola, G., Apellaniz, E., Baceta, J. I., Payros, A., Núñez-Betelu, K., Serra-Kiel, J., and Tosquella, J.: Did the Late Paleocene Thermal Maximum affect the evolution of larger foraminifers?: Evidences from calcareous plankton of the Campo section (Pyrenees, Spain), Marine Micropaleontology, 41, 45-71, 2001.

Orue-Etxebarria, X., Bernaola, G., Baceta, J. I., Angori, E., Caballero, F., Monechi, S., Pujalte, V., Dinarès-Turell, J., Apellaniz, E., and Payros, A.: New constraints on the evolution of planktic foraminifers and Calcareous nannofossils across the PaleoceneEocene boundary interval: the Zumaia section revisited, N. Jb. Geo. Palaont. Abh., 234, 223-259, 2004.

Pagani, M., Pedentchouk, N., Huber, M., Sluijs, A., Schouten, S., Brinkhuis, H., Sinninghe Damsté, J. S., Dickens, G. R., and Expedition 302: Arctic hydrology during global warming at the Palaeocene/Eocene Thermal Maximum, Nature, 442, 671-675, 2006.

Plaziat, J. C.: Late Cretaceous to late Eocene paleogeographic evolution of southwest Europe, Palaeogeogr. Palaeoclimatol. Palaeoecol., 36, 263-320, 1981.

Plink-Björklund, P. and Steel, R. J.: Initiation of turbidity currents: outcrop evidence for Eocene hyperpycnal flow turbidite, Sedim. Geol., 165, 29-52, 2004.

Pujalte, V., Baceta, J. I., Payros, A., Orue-Etxebarria, X., and SerraKiel, J.: Late Cretaceous-Middle Eocene Sequence Stratigraphy and Biostratigraphy of the SW and W Pyrenees (Pamplona and Basque Basins): a Field Seminar of the Groupe de Etude du Paleogene and IGCP Project 286, Universidad del País Vasco/Euskal Herriko Univertsitatea, 118 pp., doi:10.13140/2.1.3746.6407, 1994.

Pujalte, V., Schmitz, B., Baceta, J. I., Orue-Etxebarria, X., NúñezBetelu, K., Payros, A., and Serra-Kiel, J.: An early 'Ilerdian' transient switch-off in shallow and deep-water carbonate deposition in the Western Pyrenees, Spain: Origin and relevance for the Paleocene/Eocene boundary, Strata, 9, 111-112, 1998a.

Pujalte, V., Baceta, J. I., Orue-Etxebarria, X., and Payros, A.: Paleocene Strata of the Basque Country, W Pyrenees, N Spain: Fa- cies and Sequence Development in a Deep-water, Starved Basin, in: Mesozoic and Cenozoic Sequence Stratigraphy of European basins, edited by: de Graciansky, P. C., Hardenbol, J., Jacquin, T., and Vail, P. R., SEPM Special Publication, 60, 311-325, 1998 b.

Pujalte, V., Orue-Etxebarria, X., Schmitz, B., Tosquella, J., Baceta, J. I., Payros, A., Bernaola, G., Caballero, F., and Apellaniz, E.: Basal Ilerdian (earliest Eocene) turnover of larger foraminifera: Age constraints based on calcareous plankton and $\delta^{13} \mathrm{C}$ isotopic profiles from new southern Pyrenean sections (Spain), in: Causes and Consequences of Globally Warm Climates in the Early Paleogene, edited by: Wing, S. L., Gingerich, P. D., Schmitz, B., and Thomas, E., Geological Society of America Special Paper, 369, 205-221, 2003a.

Pujalte, V., Dinarès-Turell, J., Bernaola, G., Baceta, J. I., and Payros, A.: A reappraisal of the position of chron $\mathrm{C} 25 \mathrm{n}$ in the Campo section (Huesca province, south-central Pyrenees), Geogaceta, 34, 155-158, 2003b.

Pujalte, V., Schmitz, B., Baceta, J. I., Orue-Etxebarria, X., Bernaola, G., Dinarès-Turell, J., Payros, A., Apellaniz, E., and Caballero, F.: Correlation of the Thanetian-Ilerdian turnover of larger foraminifera and the Paleocene-Eocene Thermal Maximum: confirming evidence from the Campo area (Pyrenees, Spain), Geol. Acta, 7, 161-175, 2009.

Pujalte, V., Schmitz, B., and Baceta, J. I.: Sea-level changes across the Paleocene-Eocene interval in the Spanish Pyrenees, and their possible relationship with North Atlantic magmatism, Palaeogeogr. Palaeoclimatol. Palaeoecol., 393, 45-60, 2014a.

Pujalte, V., Robador, A., Payros, A., and Samsó, J. M.: Input of coarse-grained siliciclastics into the Pyrenean Basin during the PETM (2): a river-dominated fandelta within a carbonate platform system, Rendiconti. Online Soc. Geol. It., 31, 179-180, 2014 b.

Quesnel, F., Storme, J.-Y., Iakovleva, A., Roche, E., Breillat, N., André, M., Baele, J.-M., Schnyder, J., Yans, J., and Dupuis, C.: Unravelling the PETM record in the "Sparnacian" of NW Europe: new data from Sinceny, Paris Basin, France, in: Climate and Biota of the Early Paleogene, edited by: Egger, H., Conference Program and Abstracts, Salzburg, Austria, Berichte der Geologischen Bundesanstalt, 85, 135, 2011.

Santisteban Navarro, J. I., Martín-Serrano, A., Mediavilla, R., and Molina Ballesteros, E.: Introducción a la Estratigrafía de la Cuenca del Duero, in: Alteraciones y Paleoalteraciones en la morfología del oeste peninsular, edited by: Martín-Serrano, A., Molina Ballesteros, E., and Blanco, J. A., Instituto Geológico y Minero de España, Monografía, 4, 185-198, 1991.

Scheibner, C., Speijer, R. P., and Marzouk, A.: Larger foraminiferal turnover during the Paleocene/Eocene thermal maximum and paleoclimatic control on the evolution of platform ecosystems, Geology, 33, 493-496, 2005.

Schmitz, B. and Pujalte, V.: Sea-level, humidity, and land-erosion records across the initial Eocene Thermal Maximum from a continental-marine transect in northern Spain, Geology, 31, 689692, 2003.

Schmitz, B. and Pujalte, V.: Abrupt increase in seasonal extreme precipitation at the Paleocene-Eocene boundary, Geology, 35, 215-218, 2007.

Schmitz, B., Asaro, F., Molina, E., Monechi, S., Von Salis, K., and Speijer, R.: High-resolution iridium, $\delta^{13} \mathrm{C}, \delta^{18} \mathrm{O}$, foraminifera and nannofossil profiles across the latest Paleocene 
benthic extinction event at Zumaya, Palaeogeogr. Palaeclimatol. Palaeoecol., 133, 49-68, 1997.

Schmitz, B., Pujalte, V., and Núnez-Betelu, K.: Climate and sealevel perturbations during the Initial Eocene Thermal Maximum: Evidence from siliciclastic units in the Basque Basin (Ermua, Zumaya and Trabakua Pass), northern Spain, Palaeogeogr. Palaeoecol. Palaeoclimatol., 165, 299-320, 2001.

Schmitz, B., Pujalte, V., Molina, E., Monechi, S., Orue-Etxebarria, X., Speijer, R. P., Alegret, L., Apellaniz, E., Arenillas, I., Aubry, M.-P., Baceta, J.-I., Berggren, W. A., Bernaola, G., Caballero, F., Clemmensen, A., Dinarès-Turell, J., Dupuis, C., HeilmannClausen, C., Hilario Orus, A., Knox, R., Martin-Rubio, M., Ortiz, S., Payros, A., Petrizzo, M. R., von Salis, K., Sprong, J., Steurbaut, E., and Thomsen, E.: The Global Stratotype Sections and Points for the bases of the Selandian (Middle Paleocene) and Thanetian (Upper Paleocene) stages at Zumaia, Spain, Episodes, 34, 220-243, 2011.

Schultz, L. G.: Quantitative interpretation of mineralogical composition from X-ray and chemical data for the Pierre Shale, U.S. Geological Survey Professional Paper, 391-C, 1-31, 1964.

Segura, M. and Elorza, J.: Presencia de ventifactos en las facies Utrillas (Tamajón-Sacedoncillo, borde Suroriental del Sistema Central, Guadalajara): aspectos morfológicos y procedencia, Revista de la Sociedad Geológica de España, 26, 47-63, 2013.

Serra-Kiel, J., Hottinger, L., Caus, E., Drobne, K., Ferrandez, C., Jauhri, A. K., Less, G., Pavlovec, R., Pignatti, J., Samso, J. M., Schaub, H., Sirel, E., Strougo, A., Tambareau, Y., Tosquella, J., and Zakrevskaya, E.: Larger foraminiferal biostratigraphy of the Tethyan Paleocene and Eocene, Bull. Soc. Geol. Fr., 169, 281299, 1998.

Shackleton, N. J. and Hall, M. A.: Carbon isotope stratigraphy of bulk sediments, ODP sites 689 and 690, Maud Rise, Antarctica, edited by: Barker, P. F. and Kennett, J. P., Proceedings of the Ocean Drilling Program, Scientific Results, leg 113, 113, 985989, 1990.

Slotnick, B. S., Dickens, G. R., Nicolo, M. J., Hollis, C. J., Crampton, J S,. Zachos, J. C., and Sluijs, A.: Large-Amplitude Variations in Carbon Cycling and Terrestrial Weathering during the Latest Paleocene and Earliest Eocene: The Record at Mead Stream, New Zealand, J. Geol., 120, 487-505, 2012.
Storme, J.-Y., Devleeschouwer, X., Schnyder, J., Cambier, G., Baceta, J.I., Pujalte, V., Di Matteo, A., Iacumin, P., and Yans, J.: The Palaeocene/Eocene boundary section at Zumaia (BasqueCantabric Basin) revisited: new insights from high-resolution magnetic susceptibility and carbon isotope chemostratigraphy on organic matter $\left(\mathrm{d}^{13} \mathrm{C}_{\text {org }}\right)$, Terra Nova, 24, 310-317, 2012.

Storme, J.-Y., Steurbaut, E., Devleeschouwer, X., Dupuis, C., Iacumin, P., Rochez, G., and Yans, J.: Integrated biochemostratigraphical correlations and climatic evolution across the Danian-Selandian boundary at low latitudes, Palaeogeogr. Palaeoecol. Palaeoclimatol., 414, 212-224, 2014.

Strong, N. and Paola, C.: Valleys that never were: time surfaces versus stratigraphic surfaces, J. Sediment. Res., 78, 579-593, 2008.

Thiry, M. and Dupuis, C. (Eds.): The Palaeocene/Eocene Boundary in the Paris Basin: The Sparnacian Deposits, Field Trip Guide, Mémoires des Sciences de la Terre 34, Ecole des Mines de Paris, Paris, 91 pp., 1998.

Thiry, M. and Dupuis, C.: Use of clay minerals for paleoclimatic reconstruction: Limit of the method with special reference to the Paleocene-Eocene interval, GFF, 122, 166-167, 2000.

van Vliet, A.: Submarine Fans and Associated Deposits in the Lower Tertiary of Guipuzcoa (Northern Spain), Ph D Thesis, Lanbouwhogeschool Wageningen, the Netherlands, 45 pp., 1982.

Wing, S. L., Harrington, G. J., Smith, F. A., Bloch, J. I., Boyer, D. M., and Freeman, K. H.: Transient floral change and rapid global warming at the Paleocene-Eocene boundary, Science, 310, 993996, 2005.

Zachos, J. C., Wara, M. W., Bohaty, S., Delaney, M. L., Petrizzo, M. R., Brill, A., Bralower, T. J., and Premoli-Silva, I.: A transient rise in tropical sea surface temperature during the PaleoceneEocene Thermal Maximum, Science, 302, 1551-1554, 2003.

Zachos, J. C., Röhl, U., Schellenberg, S. A., Sluijs, A., Hodell, D. A., Kelly, D. C., Thomas, E., Nicolo, M., Raffi, I., Lourens, L. J., McCarren, H., and Kroon, D.: Rapid acidification of the ocean during the Paleocene-Eocene thermal maximum, Science, 308, 1611-1615, 2005.

Zamagni, J., Mutti, M., Ballato, P., and Kosir, A.: The PaleoceneEocene thermal maximum (PETM) in shallow-marine successions of the Adriatic carbonate platform (SW Slovenia), Geol. Soc. Am. Bull., 124, 1071-1086, 2012. 